\title{
WARTIME POLITICAL AMBITION BEHIND ONE IMAGE OF A DAM IN AUSTRALIA IS DEVELOPING A DUST BOWL (1943): US/AUSTRALIAN FILM IMAGERY, ENVIRONMENT, AND NATIONALIST STORYTELLING
}

\section{Abstract}

This paper introduces Australia is Developing a Dust Bowl, an Australian film made by Ken G. Hall for the national filmmaker Cinesound Productions during World War II. ${ }^{1}$ It also introduces an image of a scaled-down reproduction of Australia's Woronora Dam, which featured in several films of the period. The dam, this article argues, represents a broad set of ideas, many of them influenced by US conservation projects, that were being promoted in the print, film, and broadcast media of the time, and the postwar political visions driving these ideas. To identify then examine the meaning of the US ideas located in Hall's film, this paper takes a cultural and transnational approach in order to develop new insights into political and environmental history. Using this approach demonstrates that Hall's film fuses aspects of US and Australian national myth, traces of US Depression-era and wartime hopes and fears, irrigation mythology, and technological optimism. It shows that Australia's wartime politicians were determined to use this set of ideas to drive debate, gain traction, and bolster their credentials in pursuit of a nationbuilding, postwar water conservation scheme. I argue that Hall's image of a dam in Australia is Developing a Dust Bow/ represents the determination of the Australian state of New South Wales to dominate the nation's major postwar development scheme by diverting the waters of the Snowy River westward and expand the capacity of Burrinjuck Dam and develop the Murrumbidgee Irrigation Area. ${ }^{2}$

\footnotetext{
1 Drought Grips Riverina is the first title on the reel and features opening credits. Australia is Developing a Dust Bowl is the second title on the reel, and although there is no second set of opening credits, because it has its own opening title and presents a new narrative, I treat the two as separate films for the purposes of discussion. Cinesound Productions, Australia is Developing a Dust Bowl (1943), NFSA no. 0679.

2 The American Society for Environmental History supported the development of this paper with a travel grant to the ASEH 2012 conference in Madison, Wisconsin. Barry Muchnick, James Nash, and David Schorr provided important feedback. Thanks to Stephen Harris and Ruth Blair for feedback at Australia and New Zealand American Studies Association (ANZASA) 2012 and to ANZASA for the 2012 Paul Burke Travel Fellowship and a 2012 US Embassy Postgraduate Travel Bursary to support its development. Thanks to Ian Tyrrell and Grace Karskens for feedback on this developing paper at different times from 2010 through 2014, and to Elizabeth DeLoughrey for feedback at the US Studies Centre, Sydney 2014 Early Career Researcher Symposium. Thank you to my two anonymous reviewers for their contribution.
} 
Keywords: World War II; Dust Bowl; US Bureau of Reclamation; western New South Wales, soil erosion, Soil Conservation Service; dust storm; Australian Constitution; Murrumbidgee Irrigation Area (MIA); Snowy River, Snowy Mountains Hydroelectric Scheme; documentary film; desert; irrigation

\section{Introduction}

Australia is Developing a Dust Bowl (1943) was a Cinesound Review newsreel film made by Ken G. Hall for Cinesound Productions, Australia's national filmmaker. Its creation was bolstered by the ascension of state and federal Labour ${ }^{3}$ governments determined to establish national soil and water conservation programmes. The film was made to promote the conservation vision of the Australian state of New South Wales and its Labour Government under William McKell, the state's premier from 1941. Australia is Developing a Dust Bowl has evaded commentary by environmental historians, along with a broader collection of films and radio broadcasts, such as Hall's undated Conserve Water, that have remained in preservation until now, virtually buried in the national archives. Yet such films make visible the set of ideas that drove politicians and were utilised by them in pursuit of a bold wartime conservation vision. That vision involved transferring the responsibility for soil conservation and water conservation from individual Australian states to the Commonwealth government. ${ }^{4}$

This research combines a cultural methodology with a transnational approach. The cultural aspect involves investigating archival material to trace the sets of ideas expressed in historical film, print, or broadcast media imagery. This enables the study to describe the way that ideas have been expressed, or brought to life, in historical imagery, and aids in recovering material evidence of what these perspectives looked and sounded like to their political backers, creators, and audiences. This enables the broader cultural, political, and environmental contexts that gave rise to its construction to be identified.

This kind of cultural approach to investigating a broad range of historical imagery, its influences, its impotencies, and the forces shaping it, has been established in the US historical context, particularly by scholars such as Finis Dunaway,

3 The use of the spelling 'Labour', as opposed to the American spelling 'Labor', has varied over time in Australia. 'Labour' was the original spelling used until the American spelling 'Labor' is said to have been officially adopted in 1912 and is officially used today. Despite this, 'Labour' was the spelling most commonly used during the mid-1940s, including the publications of the Australian Labour Party (ALP) that have been consulted for this study, so this paper follows that usage.

4 Cinesound Productions, Australia is Developing a Dust Bowl; Cinesound Productions, Conserve Water (undated), NFSA Title: 75364. For a sustained analysis of a group of 'dust bowl' narratives promoted in Australia during World War II, see Janette-Susan Bailey, Dust Bowl: Depression America to World War Two Australia (New York: Palgrave Macmillan, forthcoming 2016). 
in Natural Visions and more recently in his Seeing Green: The Use and Abuse of American Environmental Images. ${ }^{5}$ The present study traces and describes the delayed employment of 'dust bowl' imagery in Australia. It explains the reasons it was partnered with one particular image of a dam, and describes the political context that gave this imagery its potency at this particular time in history. ${ }^{6}$

This article begins by describing both the environmental and cultural scholarship on the US Dust Bowl and New Deal-era conservation. This includes films of the period and the international scholarship describing their influence. It surveys the body of work on US-Australia transnational connections that traverse the Pacific. It then introduces a collection of 'dust bowl' imagery that has evaded attention in the Australian archives until now and considers the reasons for this in a discussion of methodology. It next describes the way that New South Wales wartime and postwar political ambitions for the Murrumbidgee Irrigation Area (MIA) gave rise to the fusion of US and Australian national narratives in films of the time where imagery evoking 'dust bowls' and the dam-building achievements of the US Bureau of Reclamation was common. Finally, it considers the benefits of the interdisciplinary methodology applied here to environmental history.

5 Finis Dunaway takes a wide range of media imagery into account, including popular literature, political prints, cartoons, film, and television in his Seeing Green: The Use and Abuse of American Environmental Images (Chicago: University of Chicago Press, 2015) and Natural Visions: The Power of Images in American Environmental Reform (Chicago: University of Chicago Press, 2005). In addition, on filmmaking and environmental contexts, see for example Gregg Mitman, Reel Nature: America's Romance with Wildlife on Films (Cambridge, MA: Harvard University Press, 1999).

6 Paired with the transnational aspect of this research approach is the cultural aspect, and this reflects the cross-disciplinary expertise of the researcher. For some of the fruits of this approach see Bailey, Dust Bowl: Depression America to World War Two Australia; “"Dust bowls", TVAs and Snowy River waters: John Heyer, The Valley is Ours and an early post-war "image of Australia"', Environment and History (forthcoming 2016), www.whp-journals.co.uk/EH/EHpapers.html, accessed 1 July 2015; 'Australian Soil Conservation Narratives of the 1940s: What can we learn?' trans. Gao Guorong, Chinese Social Sciences Today 5, no. 17 (special issue on sustainable development and ecology) (17 May 2013): 4-6. In its earliest stages of evolution, this research method was developed by taking an interdisciplinary approach, combining environmental studies and film, theatre, and performance studies methods to establish a dramaturgical model for an environmental performance. This interdisciplinary research method was developed under the leadership of creative arts/ science researcher, environmental filmmaker, producer, and verbatim playwright Professor Paul F. Brown in the Environmental Studies programme at the University of New South Wales. See Janette-Susan Bailey, 'Wind Turbine Girl: A Dramaturgical Model for an Environmental Performance' (BA Hons diss., University of New South Wales, 2005); on Brown, see for example his project, Nuclear Futures: Exposing the Legacy of the Atomic Age through Creative Arts (2015), www.nuclearfutures.org; Verbatim: Staging Memory and Community (Sydney: Currency Press, 2010); [with the] Workers Cultural Action Committee, Aftershocks, revised ed. (Sydney: Currency Press, 2001); the theatre production [with the] Maralinga Research Group, Half a Life (produced at Leeds, NSW Central Coast and Sydney, 2006); Learning for Sustainability (LfS) Research Synthesis, a report for the New South Wales Office of Environment and Heritage (Sydney: New South Wales Office of Environment and Heritage, 2012); 'Toxic Waste in our midst: towards an interdisciplinary analysis', Journal of Environmental Management 90 (2009): 1559-66. 


\section{The US Dust Bowl and New Deal Era}

This paper acknowledges the important body of work that has been created by scholars of the US on the Dust Bowl and New Deal-era conservation, among them Donald Worster, Douglas Hurt, Paul Sutter, Neil Maher, Sarah T. Phillips, Richard White, and Paul Bonnifield. ${ }^{7}$ However, focused on film imagery, this study takes a cultural approach, treating the Dust Bowl as an idea, iconic, and born of a time and place in the American experience that generated a major media event: its print, film, and broadcast media storytelling endures, filling the archives, museums and libraries of the US. This study also acknowledges the many and varied cultural studies created by those such as William Cronon, Brad Lookingbill, Charles Shindo, or Mark Andrew White. ${ }^{8}$ And while noting the claims of historians, such as Linda Gordon, who have described the Dust Bowl as a defining US national mythology, this paper adopts a transnational approach in order to acknowledge that its imagery was adopted and adapted around the world, including in Australia during World War II. ' 'Dust bowl'

7 For example, see Donald Worster, Dust Bowl: The Southern Plains in the 1930s, 25th anniversary ed. (New York: Oxford University Press, 2004); Douglas R. Hurt, The Dust Bowl: An Agricultural and Social History (Chicago: Nelson-Hall, 1981); Paul Sutter, 'New Deal Conservation: A View from the Wilderness', in FDR and the Environment, ed. Henry L. Henderson and David B. Woolner (New York: Palgrave Macmillan, 2005); Neil M. Maher, Nature's New Deal: The Civilian Conservation Corps and the Roots of the American Environmental Movement (New York: Oxford University Press, 2008); Sarah T. Phillips, This Land This Nation: Conservation, Rural America and the New Deal (New York: Cambridge University Press, 2007); Richard White, The Organic Machine: The Remaking of the Columbia River (New York: Hill and Wang, 1995); Paul Bonnifield, The Dust Bowl: Men Dirt Depression (Albuquerque, NM: University of New Mexico Press, 1979).

On the American West, see for example Donald Worster, Rivers of Empire: Water, Aridity and the Growth of the American West (New York: Pantheon Books, 1985); Patricia Limerick, Desert Passages: Encounters with the American Deserts (Niwot, CO: University of Colorado Press, 1989); Patricia Limerick, Something in the Soil: Legacies and Reckonings in the New West (New York: W.W. Norton \& Co., 2000). On the New Deal era, see for example David Kennedy, Freedom from Fear: The American People in Depression and War (New York: Oxford University Press, 1999); Richard White, It's Your Misfortune and None of my Own: A New History of the American West (Norman, OK: University of Oklahoma Press, 1991); see also Ira Katznelson, Fear Itself: The New Deal and the Origins of Our Time (New York: Liveright Publishing Corporation, 2013).

8 Those who have described the Dust Bowl in cultural studies are too numerous and too varied in their focuses to list here in full. They include William Cronon, 'A Place for Stories: Nature, History and Narrative', Journal of American History 78, no. 4 (March 1992): 1357-63; Brad Lookingbill, Dust Bowl USA: Depression America and the Ecological Imagination 1929-1941 (Athens, OH: Ohio University Press, 2001); Charles J. Shindo, Dust Bowl Migrants in the American Imagination (Lawrence, KS: The University Press of Kansas, 1997); Mark Andrew White, 'Alexandre Hogue's Passion: Ecology and Agribusiness in The Crucified Land', Great Plains Quarterly 26, no. 2 (Spring 2006): 67-83.

9 Linda Gordon, Dorothea Lange: A Life Beyond Limits (New York: W.W. Norton \& Co., 2009), 244. 
imagery was employed in Australia during the wartime decade by various parties including soil conservationists and advocates for various rival water diversion schemes in the states of New South Wales, Victoria, and Queensland. ${ }^{10}$

'Dust bowl' imagery was utilised by Ken Hall in Australia is Developing a Dust Bowl to promote the development of the MIA (established in 1912) of southwestern New South Wales. Like the broader set of media imagery produced during this period, Hall's film evoked the US Dust Bowl and the achievements of the US Bureau of Reclamation to empower an Australian nationalistic storytelling. His narrative was focused on New South Wales' ambitions for the diversion of Snowy River water westward to expand the existing capacity of Burrinjuck Dam (1928) that served the MIA (1912). The state's vision involved developing the MIA through water provision to encourage regional industries and, in turn, contribute to the goals of full employment, immigration, and population growth, as well as the process of postwar reconstruction. ${ }^{11}$

In early 2010, my research began to unearth a vast collection of print, film, and broadcast media 'dust bowl' imagery in Australian archives. While some of this material was literally buried in the nation's film, print, and broadcast media archives, a great deal of it was also freely accessible in the national archives and state and national libraries, including in digitised collections. Despite the long history of drought and erosion in south-eastern Australia, and the strong US cultural connections suggested by this set of imagery, the historiography needed to locate, record, and explain it as a collection in its own right did not yet exist, let alone any work focused on Hall's 'dust bowl' imagery. These cultural connections to the US Dust Bowl have been given attention elsewhere, including by Tom Brooking, Blaine Allan, and David Moon. They discuss the US Resettlement Administration film The Plow that Broke the Plains in the New Zealand, Canadian, and Russian contexts respectively. Works such as my Dust Bowl: Depression America to World War Two Australia and "Dust bowls",

10 The Murray River flows along the border of New South Wales and Victoria, then south into South Australia. South Australians saw little benefit for their state in proposals advanced by these three states. However, a major project to the benefit of South Australia was later proposed during the 1960s. The Chowilla storage dam was to cover 400 square miles with water where New South Wales, Victoria, and South Australia meet. The project was proposed as a major development and aspect of the Snowy Mountains scheme. It was supported by G. Vernon Lawrence of the Murray Valley Development League, who was an influential user of 'dust bowl' imagery during the 1940s. It was also supported by Prime Minister Gough Whitlam's Labour Government. However the scheme never eventuated. See Alison Painter, '21 April 1960 Chowilla Dam project', SA 175 (South Australia: Professional Historians Association, 2011), www.sahistorians.org.au/175/index.shtml.

11 On the ALP, nation-building, and the goal of full employment, see Frank Bongiorno and Nick Dyrenfurth, A Little History of the Australian Labor Party (Kensington, NSW: University of New South Wales Press, 2011), 101-3. On postwar reconstruction in Australia, see Stuart Macintyre, Australia's Boldest Experiment: War and reconstruction in the 1940s (Sydney, NSW: NewSouth Publishing, 2015); 'Women's Leadership in War and Reconstruction', Labour History: A Journal of Labour and Social History 104 (May 2013): 65-80; on postwar reconstruction in the context of soil erosion and the soil conservation debate, see Bailey, Dust Bowl: Depression America to World War Two Australia. 
TVAs and Snowy River waters', have since made a contribution to addressing that gap. However, when I first encountered this collection in early 2010, no serious study to examine it had yet been achieved. ${ }^{12}$ This is partly due to the puzzle the whole collection of transnational 'dust bowl' imagery presented.

The US Dust Bowl occurred in the 1930s. South-eastern Australia suffered severe drought and wind erosion across a similar period. Australian soil conservationists were well aware of the US Dust Bowl problem, New Deal soil conservation initiatives, and the huge media event generated by them both. The Australian media portrayed the Dust Bowl as an American tragedy and one Australians should take heed of. However, the idea of a specifically Australian 'dust bowl' did not automatically gain currency. There was a time lapse in the transnational transfer of 'dust bowl' imagery that was to be interpreted in this way. It took hold in the media in the following decade. The delayed transfer of this imagery into World War II raised political and cultural questions that could not be explained simply by comparing the severe drought and erosion conditions of both countries in the 1930s.

The questions presented by this collection of imagery, as well as the question of a gap in the historiography, are also a reflection of the fact that, as historian of the US and Australia Ian Tyrrell has observed, 'American history has been given

12 For international perspectives, both cultural and scientific, see Tom Brooking, Applied Science to the Rescue', Environmental History 12 (special issue: Films Every Environmental Historian Should See) (2007): 292-4; Bailey, Dust Bowl: Depression America to World War Two Australia and "DDst bowls", TVAs and Snowy River waters'; David Moon, The Plough that Broke the Steppes: Agriculture and Environment on Russia's Grasslands, 1700-1914 (Oxford: Oxford University Press, 2013); Blaine Allan, 'Canada's Heritage (1939) and America's The Plow that Broke the Plains (1936)', Historical Journal of Film, Radio and Television 19, no. 4 (1999): 441-72; 'Making Heritage, a Canadian Government Motion Picture', Prairie Forum 29, no. 1 (Spring 2004): 85-102; 'A National "as distinct from Departmental" Film Board, and the Case of Heritage', Canadian Journal of Film Studies 2, no. 1 (Spring 2000): 30-54; Deane M. Williams, 'Heyer, John', in Encyclopedia of Documentary Film, vol. 1, ed. Ian Aitken (New York: Routledge, 2006), 558-9. 'International Documentary Filmmaker: John Heyer [14/9/1916-19/6/2001]', Metro, no. 129/130 (Spring 2001): 248-53. The following papers have discussed New South Wales and Victorian film imagery, including Ken Hall's Cinesound Review films: Janette-Susan Bailey, 'Australia's Dust Bowl: Reception and interpretation of an environmental idea' (paper presented at the American Society for Environmental History Conference, March 2012, Madison, Wisconsin); 'Australia is Developing a Dust Bowl: A heritage of transnational environmental ideas in one image of a dam' (paper presented at the United States Studies Centre/ANZASA conference, University of Sydney, December 2015); 'Watering Australia's "Dust Bowl": An American Idea in the Minds of Australians of the 1930s and 1940s' (paper presented at the ANZASA 2012 biennial conference, Brisbane); 'A Dust Bowl in Australia? US and Australian newsreels of the nineteen thirties and forties as transnational carriers of an environmental idea' (paper presented at the School of Humanities, History Postgraduate Seminar, University of New South Wales, 15 March 2012); ‘Deserts, Old World civilizations and New World Dust Bowls: Something to fear in the nineteen-thirties and forties' (paper presented at the University of New South Wales School of History and Philosophy 3rd Annual Postgraduate Research Conference, 8 September 2011); “'Dust bowls", TVAs and Snowy River waters: Transnational environmental imagery' in John Heyer and Pare Lorentz, 'The River, The Plow and The Valley is Ours' (paper presented at Broken Images: A Symposium on Early American Photography in the Asia Pacific, 1850-1950, Griffith Centre for Cultural Research, July 2014); 'The Dust Bowl and Australia: A transnational study of the reception and interpretation of environmental ideas' (paper presented at the School of History and Philosophy Postgraduate Seminar, University of New South Wales, 14 October 2010). 
little attention in the vast and influential area of environmental history practiced in Australia', where US developments have primarily been observed 'casually and imperfectly from a distance' ${ }^{13}$ By focusing on one image of a model dam, this paper demonstrates the benefits to Australian political and environmental history of applying a combined transnational and cultural research approach. This approach has illuminated the place where Australian and US national narratives are fused in Hall's film imagery. In doing this, the methodology begins to address questions posed by the neglected broader collection of 'dust bowl' imagery to which Hall's film belongs. At the same time, this paper aims to make a contribution to the expansion of work on US-Australia transnational connections that traverse the Pacific. ${ }^{14}$

The body of work in this area includes Stephen Powell's 'Mothering, Husbandry and the State', a section of his doctoral thesis describing the 1930s establishment of soil conservation services within a US-Australia exchange of ideas; Donald Meinig's 1962 cultural landscape study On the Margins of the Good Earth; Kirsty Douglas' 'For the Sake of a Little Grass'; and David Goodman's study of the Californian and the Australian goldfields of the 1850s, Gold Seeking. ${ }^{15}$ Ian Tyrrell's True Gardens of the Gods is a transnational environmental history that investigates garden imagery - the idea or dream of transforming deserts to

13 Ian Tyrrell, 'From the Wet and Mud of Newcastle: Reflections on ANZASA and U.S. History in Australia, 1974-2012', Australasian Journal of American Studies 32, no. 1 (July 2013): 74; examples of efforts to draw attention to Australia's environmental, or related rural/social or economic, policy-making, or scientific parallels, similarities, or differences, through a retrospective application of 'dust bowl' terminology have included Neil Barr and John Cary, Greening a Brown Land: The Australian Search for Sustainable Land Use (Crows Nest, NSW: Macmillan Education Australia, 1992), 131-2; Libby Robin, 'Paul Sears: Deserts on the March, 1935', in The Future of Nature, ed. Libby Robin, Sverker Sörlin, and Paul Warde (New Haven, CT, and London: Yale University Press, 2013), 184; Cameron Muir, The Broken Promise of Agricultural Progress: An environmental history (Hoboken: Taylor and Francis, 2014), 128-32. On the terminology 'dirty thirties' (describing the US Dust Bowl and the Canadian case) see Worster, Dust Bowl, 13. For Australian context see also Libby Robin, ‘Ecology: A Science of Empire?', in Ecology and Empire: Environmental History of Settler Societies, ed. Tom Griffiths and Libby Robin (Carlton South, Vic.: Melbourne University Press, 1997), 63-76.

14 This paper focuses on Australia but acknowledges that scholars such as Tom Brooking and James Beattie have drawn the US Dust Bowl and soil erosion issues into a discussion of South Asia and New Zealand contexts, in James Beattie, Empire and Environmental Anxiety: Health, Science, Art and Conservation in South Asia and Australasia, 1800-1920 (Basingstoke: Palgrave Macmillan, 2011); 'Environmental Anxiety in New Zealand, 1840-1941: Climate Change, Soil Erosion, Sand Drift, Flooding and Forest Conservation', Environment and History 1, no. 9 (November 2003), 388; Brooking, 'Applied Science to the Rescue'.

15 Stephen Powell, 'Mothering, Husbandry and the State: Conservation in the United States and Australia, 1912-1945', (PhD diss., Monash University, 2000); Donald Meinig, On the Margins of the Good Earth: The South Australian Wheat Frontier 1869-1884 (Adelaide: Rigby, 1962; 1970); Kirsty Douglas, "“For the Sake of a Little Grass": A comparative history of settler science and environmental limits in South Australia and the Great Plains', in Climate, Science, and Colonization: Histories from Australia and New Zealand, ed. James Beattie, Emily O'Gorman, and Matthew Henry (Basingstoke: Palgrave Macmillan, 2014), 99-117; David Goodman, Gold Seeking: Victoria and California in the 1850s (St Leonards, NSW: Allen and Unwin, 1994); Ian Tyrrell, True Gardens of the Gods: Australian-Californian Environmental Reform 1860-1930 (Berkeley, CA: University of California Press, 1999), 2. Tyrrell describes the transnational influences behind the transformation of Mildura in northern Victoria's Mallee region. 
irrigated landscapes. ${ }^{16}$ J. M. Powell, Tom Griffiths, Tim Sherratt, and Ian Tyrrell each have described Australia's Snowy Mountains Scheme as strongly influenced by the idea of US technologies capable of turning deserts into green oases. ${ }^{17}$ However, it is Tyrrell whose central focus is on activity both in and between California and Australia, and he takes this investigation up to the 1930s.

Despite this body of work, it is harder to find cultural studies that clearly show what transnational environmental imaginings of the past actually looked like or sounded like in Australian comparative or transnational contexts. An exception is the art historian Erika Esau's Images of the Pacific Rim: Australia and California, 1850-1935. Tyrrell has described Esau's work as 'the first to focus squarely on visual representations of Australian and Californian landscapes and culture in transnational perspective', adding that it contributes 'to a growing understanding of these cultural connections' ${ }^{18}$ Esau's is a history of the circulation between California and Australia of commercial art, design, and architectural styles. She beautifully illustrates how a transnational idea from the past can be seen today. Esau recovers and draws together a collection of images expressing a transnational set of ideas that were shared between the US and Australia during the nineteenth and early twentieth centuries. Her collection, including posters, journals, and fruit box labels shows Californian scenes featuring Eucalypts and flowering gums that look as if they are set in Australia. We see images of the Australian landscape and architecture that could very easily be in California, or perhaps in Australia - with transnational images, as Esau's work demonstrates, it is difficult to tell. ${ }^{19}$

16 Outside of a cultural, transnational, or comparative Australian focus, among the US-centred studies focused specifically on water and the American West, are Worster's Rivers of Empire; White, The Organic Machine, 51-2; Marc Reisner, Cadillac Desert: The American West and its Disappearing Water (New York: Viking, 1986); Mohamed T. El-Ashry and Diana C. Gibbons, eds, Water and Arid Lands of the Western United States (Cambridge: Cambridge University Press, 1988). For a US-China comparative study, see Donald Worster, 'The Flow of Empire: Comparing Water Control in the United States and China', RCC Perspectives 5 (2011).

17 On 'America watching', see J. M. Powell, 'The Empire Meets the New Deal: Interwar Encounters in Conservation and Regional Planning', Geographical Research 43, no. 4 (December 2005), 344; on 'unmistakable echoes' of the TVA, see 339. On US influences, see Tyrrell, True Gardens of the Gods, 173; on the TVA model, see Tom Griffiths and Tim Sherratt, 'What if the northern rivers had been turned inland?', in What If: Australian History as it Might Have Been, ed. Stuart Macintyre and Sean Scalmer (Carlton, Vic.: Melbourne University Publishing, 2006), 238; see also Michael Cathcart, The Water Dreamers: The Remarkable History of our Dry Continent (Melbourne: Text Publishing, 2009), 241.

18 Ian Tyrrell, foreword to Erika Esau, Images of the Pacific Rim: Australia and California, 1850-1935 (Sydney: Power Publications, 2010), 8.

19 Esau, Images of the Pacific Rim. 
Along with my Dust Bowl and "'Dust Bowls", TVAs and Snowy River Waters', this paper aims to expand the exploration of these transnational themes further into the World War II and early postwar years. ${ }^{20}$ It is this cultural and transnational approach that has enabled the identification of issues that would otherwise remain undetected in Australian environmental history and has permitted it to reach into areas not usually accessed. This approach has also enabled the study to expand the discussion of 'dust bowl' imagery beyond the 1930s and locate Hall's imagery, and its connection to the nation's history, within the context of 'a range of processes that transcend national boundaries' ${ }^{21}$

\section{Ken Hall: Transnationalism as a storytelling strategy}

Described as one of Australia's most successful pioneering filmmakers, Ken G. Hall was the first Australian to win an Oscar (in 1943), for the newsreel film Kokoda Front Line! ${ }^{22}$ He was head of Cinesound films for 25 years. Hall also produced 'dust bowl' imagery that expressed the wartime vision for a national conservation agenda. ${ }^{23}$ Film expert Ray Edmondson has explained that while Hall was head of the company, Cinesound took 'an explicit or implicit editorial line on issues ... certainly on the environment' ${ }^{24}$ His documentary films, such as Drought Grips Riverina and Australia is Developing a Dust Bowl, were treated as proof of the kinds of changes that were needed and inspired urgent calls for action from state and federal parliamentarians. ${ }^{25}$

\footnotetext{
20 Bailey, “'Dust Bowls”, TVAs and Snowy River waters'; Bailey also completed a PhD on transnational 'dust bowl' imagery in 2014; for a rich cultural study that explores the Russian context, see Dorothy ZeislerVralsted, 'The Cultural and Hydrological Development of the Mississippi and Volga Rivers', in Rivers in History: Perspectives on waterways in Europe and North America, ed. Christof Mauch and Thomas Zeller (Pittsburgh, PA: University of Pittsburgh Press Digital Editions, 2008).

21 Sharon Crozier-De Rosa and David Lowe, 'Nationalism and Transnationalism in Australian Historical Writing', History Australia 10, no. 3 (December 2013): 8-9.

22 War cameraman Damian Parer was killed while shooting this film footage at the time Australians halted the Japanese land forces at Milne Bay, defeating them on 2 November 1942 at Kokoda in the Owen Stanley Ranges - the infamous Kokoda Track. See Neil McDonald, 'Parer, Damien Peter (1912-1944)', Australian Dictionary of Biography, adb.anu.edu.au/biography/parer-damien-peter-11339/text20251.

23 'Filmmaker Ken G. Hall dead at 92', Canberra Times, 10 February 1994, 1; 'Obituary: Ken G. Hall', The Independent [London], 27 August 2015; Ken G. Hall, Directed by Ken G. Hall: Autobiography of an Australian Film-maker (Melbourne: Lansdowne, 1977).

24 Ray Edmondson, 'The Voice of Australia: Cinesound Review', Metro, no. 137 (2003): 138-40.

25 See Bailey, Dust Bowl: Depression America to World War Two Australia for a discussion of films such as Movietone's Spectre of Drought and Cinesound's Victorian Drought: Mallee Country Facing Ruin, both describing a dust bowl in north-west Victoria's Mallee wheatlands during the late 1930s and 1940s; on films focused on Victoria featuring 'dust bowl' and TVA imagery made by John Heyer for the National Film Board later in the decade, see Bailey, "'Dust Bowls", TVAs and Snowy River waters'.
} 
The imagery Hall constructed reflects the set of ideas drawn from both the US and Australian experience that were circulating more widely at a time when south-eastern Australia was suffering under increasingly severe drought conditions. By time the war began, severe drought had already destroyed protective vegetation cover across the Australian continent. ${ }^{26}$ Water shortages were common, and wind erosion brought dramatic dust storms - sand drift, dust haze, dramatic dust clouds, or dust fog were widespread. ${ }^{27}$ The Australian Bureau of Meteorology has described these drought conditions as 'more or less endemic' for eastern Australia between 1937 and 1945, with record low rainfalls for New South Wales from 1937. Intensifying drought conditions occurred in other states the next year, while 1940 was 'one of the driest years of the century for most of southern Australia'; by 1945 large rivers had 'virtually dried up'. ${ }^{28}$ Recent reports have confirmed that western New South Wales was among 'the major wind erosion regions in Australia' ${ }^{29}$

Under McKell, the erosion survey of New South Wales had been completed by 1943 and its results were published in the first issue of the Journal of the Soil Conservation Service of New South Wales in April 1945. ${ }^{30}$ It showed 18,650 square miles of 'moderate' and 974 square miles of 'severe' wind erosion across 184,869 square miles of agricultural land in the Eastern and Central Divisions, much of it 'beyond economic reclamation'. However, the pastoral lands (ranches) of the western division - the focus of so much debate about 'dust bowls' — were not included in this survey. The first coherent classification and map of the vegetation of western New South Wales was produced in 1948 by the botanist Noel Beadle (Map 1). ${ }^{31}$ As his findings confirmed, the overstocking of sheep was a major contributing factor; however, it was part of a set of interrelated

26 G. H. McTainsh, J. F. Leys, T. O'Loingsigh and C. L. Strong, Wind Erosion and Land Management in Australia during 1940-1949 and 2000-2009, report prepared for the Australian Government Department of Sustainability, Environment, Water, Population and Communities (Canberra: DSEWPaC, 2011 ), 17.

27 F. Loewe explained that 'the duststorm phenomenon in Australia has been frequently described in literature in a non-scientific way' in 'Duststorms in Australia', Commonwealth Meteorological Bureau Bulletin, no. 28 (Melbourne: H. E. Daw, Government Printer, 1943): 5-6. Part of the reason for this was that a clear understanding of the difference between 'sand and dust in the atmosphere' had not yet fully developed. Each term describes a different manifestation of wind behaviour and relates to the lifting of various soil types to different heights, with varied storm breadths, and travelling for different distances, or falling back to the ground over different time frames (i.e. lighter particles take longer to settle).

28 Australian Government Bureau of Meteorology, 'The World War II droughts 1937-45', reg.bom.gov.au/ lam/climate/levelthree/c20thc/drought3.htm, accessed April 2010.

29 McTainsh et al., Wind Erosion, 9.

30 L. G. Kaleski, 'The Erosion Survey of N.S.W. (Eastern and Central Divisions)', Journal of the Soil Conservation Service of NSW (April 1945): 14. On McKell's career, his environmental achievements, and environmental conditions, including erosion affecting central New South Wales, within a discussion of modern agriculture, see Muir, The Broken Promise of Agricultural Progress, particularly 109-39; on historical stocking rates, see 29; and on impacts on indigenous Australians, see 30-1. On pastoralism, Aboriginal Australians, and overstocking in late nineteenth century New South Wales, see Heather Goodall, Invasion to Embassy: Land in Aboriginal Politics in New South Wales, 1770-1972 (Sydney: University of Sydney Press, 2008), 68, 72, 82-5. 31 Kaleski, 'The Erosion Survey', 14. At the time of the journal's publication, final maps were still being drafted. On Beadle, see also Bailey, Dust Bowl: Depression America to World War Two Australia. 
contributors. They included wartime manpower, transport, and other resource shortages that left the rabbit problem or grasshopper plagues unattended. Edible native vegetation was depleted by drought, and paddocks left bare of this feed led to the overstocking of sheep, which in turn caused further depletion of vegetation and left topsoil exposed to the wind. Across the wartime period, the south-eastern states sweltered under heatwave conditions, accompanied by severe water shortages, while for the nation, both war and drought came to an end together, in August 1945. ${ }^{32}$

\section{"Australian Dust Storm locations 1943 and New South Wales land divisions based on the NSW Crown Lands Acts."}

Janette-Susan Bailey (Sydney, 2011), adapted from Loewe, "Duststorms in Australia," Commonwealth Meteorological Bureau Bulletin, no. 28 (1943), 7; New South Wales Department of Lands, Map of New South Wales: showing all divisions for the purposes of the Crown Lands acts, 1907, National Library of Australia.

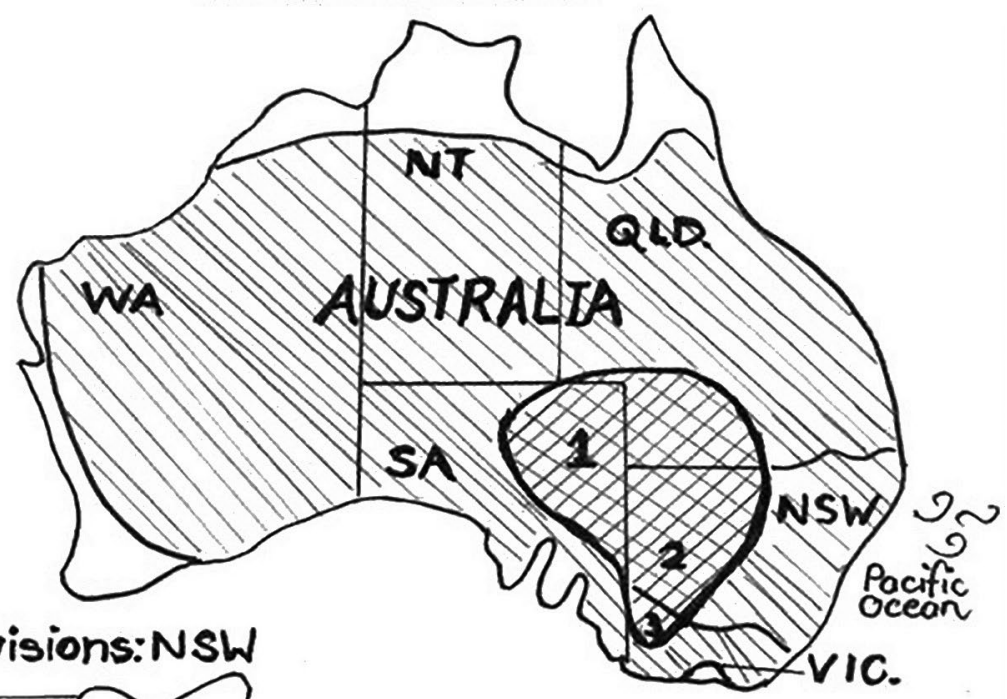

Land Divisions:NSW

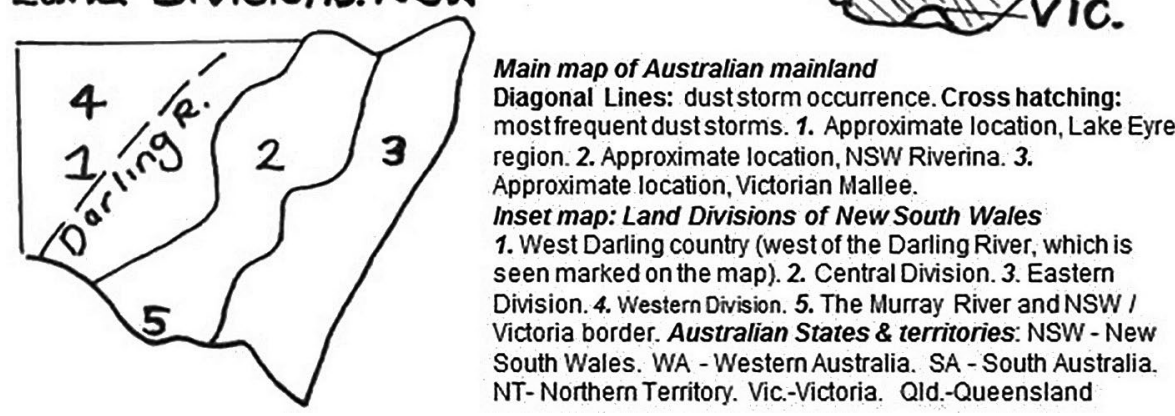

Map 1: Australian dust storm locations 1943 and New South Wales land divisions based on the NSW Crown Lands Acts.

Source: Adapted from F. Loewe, 'Duststorms in Australia', Commonwealth Meteorological Bureau Bulletin, no. 28 (Melbourne: H. E. Daw, Government Printer, 1943); NSW Department of Lands, Map, Crown Lands Acts (1907) (Sydney, 2011). 
With the fall of Singapore on 15 February 1942 and an escalation of the conflict in the Pacific, this was also a time of heightened patriotism and, consequently, concern about the war effort, enemies, traitors, and invasion. This wartime sentiment influenced the way that concerns over soil erosion were expressed and the publicity generated to address it by the newly established NSW Soil Conservation Service. In print, film and broadcast media imagery, graziers, sheep, erosion, expert-driven science, and soil conservation all came to be associated with the idea of another, even more serious battle being waged in the South-West Pacific.

The New South Wales state government had established the pioneering Soil Conservation Service in 1938 under the direction of Sam Clayton. The service promoted US-style innovations and became known for supporting the idea of expert-driven science and advice, while decentralising activity as was the American model in their soil conservation programme. ${ }^{33}$ What McKell wanted in the 1940s was to see his own state's conservation funding and research achievements duplicated at the national level. He envisioned a national Australian soil conservation service. His vision was shared by Prime Minister John Curtin, state Labour leaders, Minister for External Affairs Bert Evatt, Minister for Information Arthur Calwell, and soil conservationists across the nation. Along with McKell, soil conservationists believed that constitutional change was needed if co-operation from the states was ever to be achieved on water and soil conservation management. ${ }^{34}$ Under Curtin, the Labour Commonwealth Government sought constitutional change, calling for 14 powers to be transferred from the states to the Commonwealth to achieve postwar reconstruction - a transfer of powers that would have enabled them to take control over both water and soil conservation. ${ }^{35}$ Along with fellow advocates, McKell was inspired by the New Deal and federally regulated initiatives that centralised control and decentralised activity. These included

33 See Powell, 'The Empire Meets the New Deal', 349; Roland Breckwoldt, The Dirt Doctors: A Jubilee History of the Soil Conservation Service of NSW (Sydney: Soil Conservation Service of NSW, 1998), 44.

34 Australian Labour Party, Five Critical Years: The Story of the McKell Labour Government in New South Wales, May 1941 - May 1946 (Sydney: Australian Labour Party, 1946), 40.

35 On conservation visions and the 'fourteen powers' referendum, see also Bailey, Dust Bowl: Depression America to World War Two Australia; see also Macintyre, Australia's Boldest Experiment, 255-7. 
the US Soil Conservation Service (established in 1935) and the US Bureau of Reclamation (1902), while the dam-building of the Tennessee Valley Authority (TVA, established in 1933) was also of interest. ${ }^{36}$

In May 1943, the Commonwealth Government Minister for Post-war Reconstruction, J. B. Chifley, called for proposals from the Australian states for a postwar national works programme with the twin goals of irrigation and hydroelectric power development. New South Wales was the only state government to submit a proposal in response to the National Works Council, a plan created by their own Water and Soil Conservation Advisory Committee. ${ }^{37}$ What New South Wales wanted was to divert the waters of the Snowy River westward and expand the capacity of the Murrumbidgee River. In turn, this would develop the MIA in the drought-affected Riverina district (Map 2). ${ }^{38}$ Rival proposals soon followed, including from the state of Victoria. Victorians proposed to develop the Murray River Valley at the border of both states. This led to extended debate over the entire decade. ${ }^{39}$ The focus of this work, however, is on the year 1942 and on New South Wales and its nation-building vision for transforming the Riverina with Snowy River waters.

\footnotetext{
36 The period 1935 to 1938 is commonly understood as the New Deal period when an innovative focus on social reform and conservation ideas developed together in the US. Those agencies that worked directly to attack the problem of wind erosion on the Great Plains included the Department of Agriculture; the Forest Service, which planted shelter belts of trees; and the Soil Conservation Service, which collaborated with the Civilian Conservation Corps. On New Deal conservation ideas, see Donald Worster, Nature's Economy: A History of Ecological Ideas, 2nd ed. (New York: Cambridge University Press, 1994), 232. On a 'new agricultural conservation', see Worster, Dust Bowl, 190; Phillips, This Land This Nation, 22; on economic recovery, see 2-3; on the influence of New Deal resource management upon the modern American state, see 4; and on rural poverty, see 9; Dunaway, Natural Visions, 52, 47-51. On the TVA and the Civilian Conservation Corps as manifestations of 'total conservation' ideas, see Maher, Nature's New Deal, 203-10. On conservation programme as work relief, see Sutter, 'New Deal Conservation', 87-90. See also Joseph Gaer, United States Department of Agriculture, Toward Farm Security: The Problem of Rural Poverty and the Work of the Farm Security Administration (Washington, DC: G.P.O., 1941); McKell visited the TVA: see W. J. McKell, Tennessee Valley Authority (U.S.A.) (Parliament of New South Wales, 5 December 1945). On McKell's interest in the TVA and regional planning see Bailey, Dust Bowl: Depression America to World War Two Australia and "'Dust bowls", TVAs and Snowy River waters'.

37 On electrical facilities, see Wigmore, Struggle for the Snowy: The Background of the Snowy Mountains Scheme (Melbourne: Oxford University Press, 1968), 103; on the Advisory Committee, see 103-4.

38 For the original map, see The Snowy River Scheme: Region Affected by the Diversion Proposals, 1946, Department of Post-war Reconstruction-Snowy River Diversion, National Archives of Australia, series A12542, item 12 .

39 For analysis of film, print, and broadcast media imagery constructed to support the Victorian vision for a Murray Valley TVA, and on the role of the Murray Valley Development League under the leadership of G. Vernon Lawrence, see Bailey, Dust Bowl: Depression America to World War Two Australia and “"Dust bowls", TVAs and Snowy River waters'.
} 


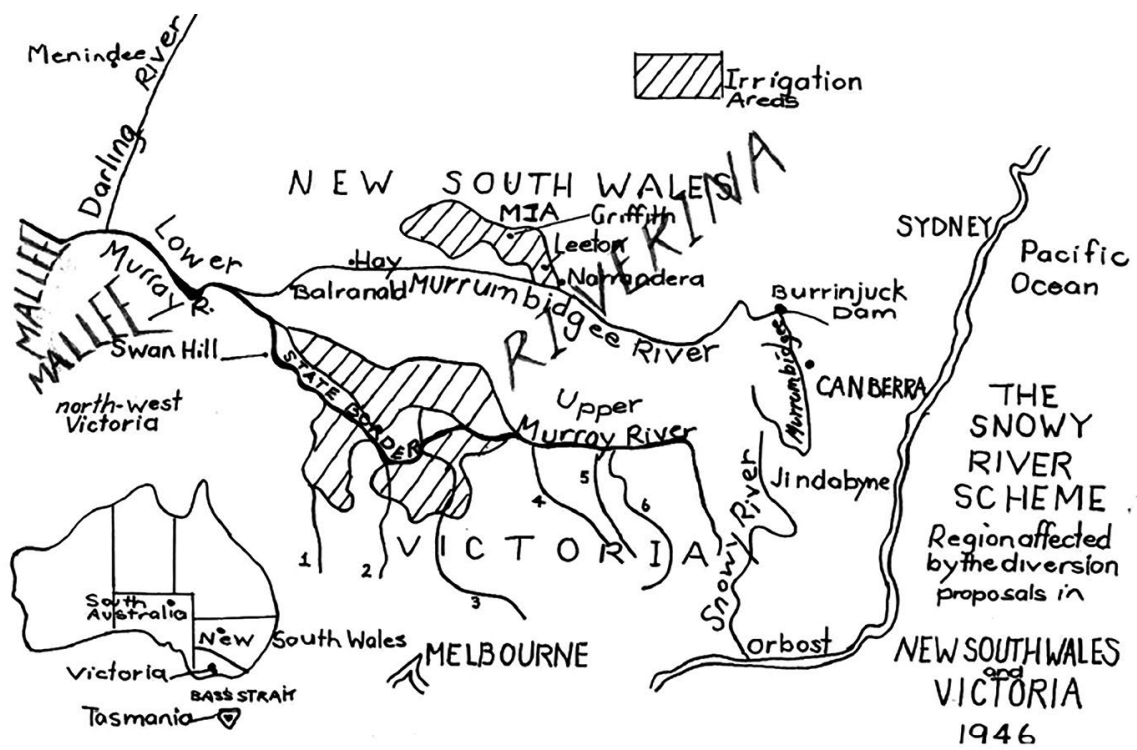

The Murray River marks the state border of New South Wales to the north and Victoria to the south Key to Victorian Rivers: 1. Lodden. 2. Campaspie. 3. Goulburn. 4. Ovens. 5. Kiewa. 6. Mitta Mitta Janette-susan Bailey, Snowy, Murrumbidgee, Murray 1946, 2013. Adapted from the hand-drawn original, The Snowy River Scheme: Region Affected by the Diversion Proposals, Department of Post-war Reconstruction, Australia (1946).

Map 2: Snowy, Murrumbidgee, Murray 1946.

Source: Map adapted from the Department of Post-war Reconstruction's hand-drawn original, The Snowy River Scheme: Region Affected by the Diversion Proposals, 1946 (Sydney, 2013).

Irrigation areas are marked by diagonal lines. In New South Wales these areas include Narrandera, Leeton, and Griffith in the Murrumbidgee Irrigation Area to the north (Riverina region). The Murrumbidgee waters eventually meet the lower Murray River. The Murray marks the New South Wales-Victoria state border. The Snowy River can be seen rising in the Australian Alps in New South Wales.

Ken Hall dramatised this nationalistic vision in films such as Australia is Developing a Dust Bowl, Drought Grips Riverina, and Conserve Water. In these, he turned to aspects of both US and Australian national narrative, while also drawing on his understanding of the Pacific conflict and Australian wartime sentiment to empower his message. Throughout December 1941 and into early 1942, not long before the film was released, Curtin had pressured Winston Churchill to honour his commitment to send forces to defend Australia, because Australia's armed forces were locked in combat far from home, in Europe, the Middle East, and North Africa. During this period, the Japanese offensive advanced southward towards Singapore, but despite Curtin's efforts, little help 
was forthcoming from Churchill, whose focus was a policy of 'beat Hitler first' ${ }^{40}$ Just before the new year in 1942 and fearing Japanese invasion, Curtin wrote a now famous message to the nation, in which he stressed the possibility of turning to the United States for assistance in the defence of Australia. Not long after he delivered that message, Australians were shocked when inadequate British defences in Malaya swiftly fell to advancing Japanese forces. British, Australian, and Indian troops then staged a desperate last defence at Singapore before they capitulated to the Japanese on 15 February $1942 .{ }^{41}$

Australian writers responded with fury. In March 1942 the Australian Women's Weekly published a poem, Singapore, by celebrated Australian Poet Dame Mary Gilmore (Figure 1). It was a gut-wrenching response expressing Australians' sense of anger, fear, and betrayal by the British. She described a beleaguered Singapore looking to the skies for Allied support, and the now 'dead and captive sons of Australia'. She called for revenge for 'allied incompetence and corruption' in Singapore. ${ }^{42}$ Known for his pacifist views, Curtin now warned Australians that there would be no turning back. He said, 'fate has willed our position in this war' ${ }^{43}$

\footnotetext{
40 On the competition for resources for the Pacific and European theatres of war, see Sean Brawley, Chris Dixon, and Beatrice Trefalt, Competing Voices from the Pacific War (Santa Barbara, CA: Greenwood Press, 2009), 69; on isolating Australia, see 96; and on not treating the Pacific as subordinate, see 12. On the Allies' policy of 'beat Hitler first' that split resources 30/70 between the Pacific and European theatres, see Brawley et al., Competing Voices, 49, 119; on beating Hitler first and the national alarm over the enemy advance, see also Bailey, Dust Bowl: Depression America to World War Two Australia; Macintyre, 'Women's Leadership in War and Reconstruction', 69-70 and Australia's Boldest Experiment, 91.

41 Pearl Harbor occurred in the early hours of 8 December 1941, eastern Australian time. For details of this series of events up until the new year, including War Cabinet decisions, see David Day, 'John CurtinIn Office', in Australia's Prime Ministers (Canberra: National Archives of Australia), primeministers.naa.gov. $\mathrm{au} /$ primeministers/curtin/in-office.aspx\#section4. On Australians in the Middle East, see Barton Maughan, 'Tobruk and El Alamein', in Australia in the War of 1939-1945, vol. 3 (Canberra: Australian War Memorial, 1966), 401. For a list of the Australian divisions at Tobruk and a list of casualties, see Australian War Memorial, Siege of Tobruk, www.awm.gov.au/encyclopedia/tobruk/. See also Mark Johnston and Peter Stanley, Alamein: The Australian Story (Melbourne: Oxford University Press, 2002). On casualties at El Alamein, see Australian War Memorial, El Alamein Battles, www.awm.gov.au/encyclopedia/el_alamein/reading/. On the series of events across late 1941 and 1942, including Malaya, see Day, 'John Curtin - In Office'. See James Curran, Curtin's Empire (Cambridge and New York: Cambridge University Press, 2012), 11, on the much debated aspects of Curtin's speech.

42 Mary Gilmore, Singapore, in 'Dame Mary Gilmore's Poem: Singapore', Australian Women's Weekly, 14 March 1942.

43 For Curtin's reference to 'fate', see Day, 'John Curtin-In Office'.
} 


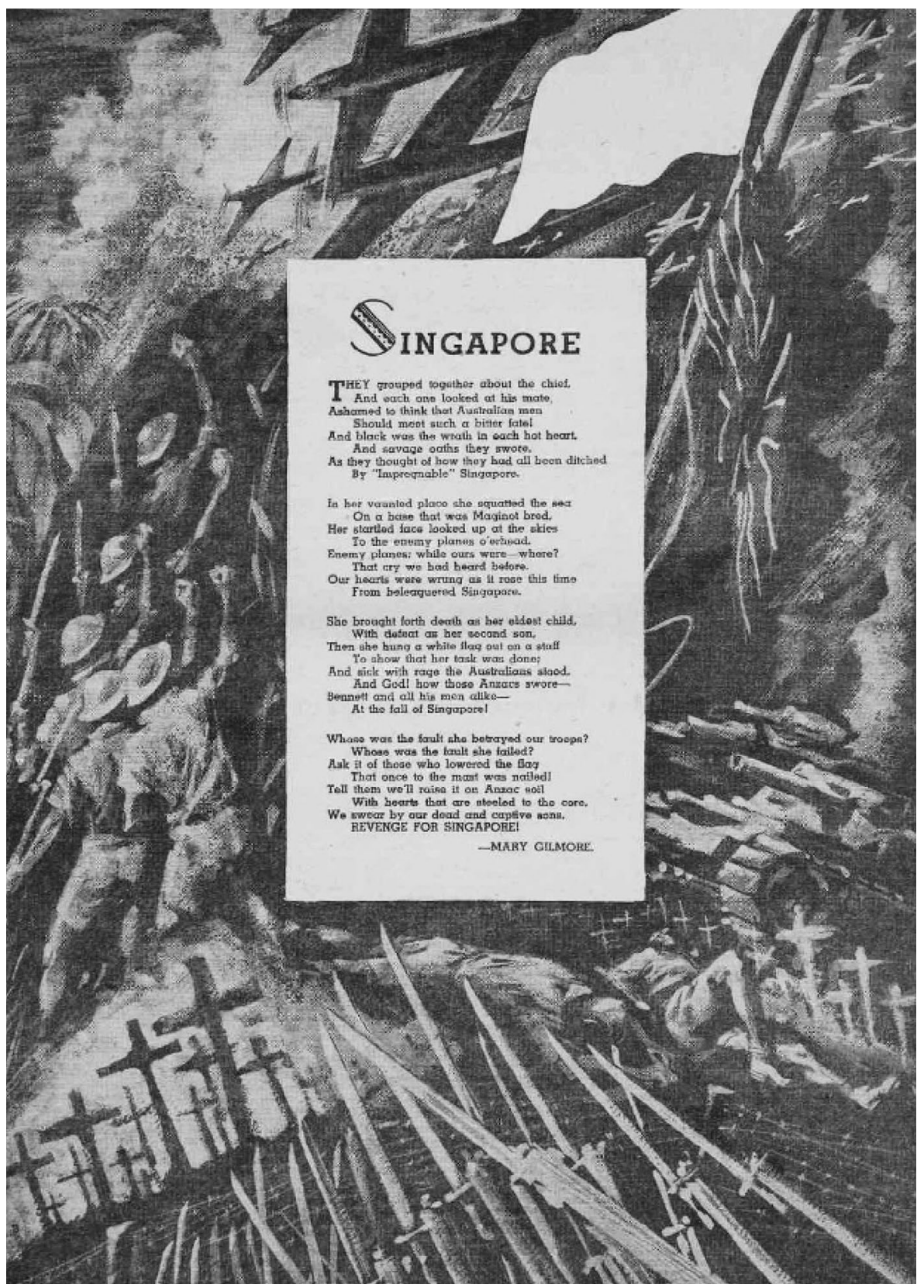

Figure 1: A visual expression of anger and fear. 'Dame Mary Gilmore's Poem: Singapore'. Soldiers can be seen strewn on the battlefield to the right below the text (leg raised), and below-centre (lying face down). Their graves rise from the image, as do bayonets in the foreground. Their fists are raised in defiance as enemy planes besiege Singapore and the white flag is raised above Britain's Union Jack at top right.

Source: Australian Women's Weekly, 14 March 1942. 
Amidst bombing raids against northern Australia and midget-submarine attacks on Sydney, and while suffering under worsening drought and erosion conditions, Australia was under pressure to produce food for millions in the Pacific, India, and Britain. Meanwhile, Australia also prepared to provide food and shelter for an influx of hoped-for evacuees from Singapore and Malaya in the autumn with absolutely no knowledge of who or how many would arrive, or how far south the Japanese intended to push. ${ }^{44}$ At a time when Australians were daily experiencing a heightened sense of national emergency, Hall aimed to appeal to the emotions of a broad wartime audience - both rural and urban. ${ }^{45}$ For the nation, concerns about drought, dust storms, sand drift, food shortages, water shortages, heat waves, rabbit plagues, overstocking, sheep starvation, food rationing, increased food production quotas, and war-as Gilmore had so eloquently expressed it in Singapore - went hand in hand. ${ }^{46}$

\section{The sheep myth and US Dust Bowl irrigation dreams}

Hall drew his knowledge of these wartime tensions, sentiment, and severe drought into a retelling of a powerful Australian national myth, that of the nation riding on the sheep's back'. He told a story about the Riverina in western New South Wales, a region famous for breeding some of the finest Merino sheep in the world and home of the MIA. The myth of the nation riding on the sheep's back was based on the history of squatters (pastoralists) whose huge runs had given them a monopoly over the lands of western New South Wales. The industry of large landowners was said by some to provide an economic backbone to the nation, buoying primary industry with products such as wool. ${ }^{47}$ Hall's film was a commentary on a series of nineteenth- and early twentieth-century debates and legislation that eventually resulted in a more egalitarian distribution of lands. But with these changes, there was no corresponding amendment to the

\footnotetext{
44 On food supplies, see Australian Labour Party, Five Critical Years, 26; on eggs, see 28. On air raids, see Daniel Connell, The War at Home: Australia 1939-1949 (Crows Nest, NSW: ABC Enterprises for the Australian Broadcasting Corporation, 1988), 28; on manpower, various shortages, and food for US and Australian troops, see 26, 103; on the calling-up of married and older men, see 88-9.

45 See Elizabeth Rechniewski, 'Remembering The Battle for Australia', PORTAL 7, no. 1 (January 2010): 6, epress.lib.uts.edu.au/journals/index.php/portal/article/view/1153. On the end of Japanese expansion, see Brawley et al., Competing Voices, 70. On Australia's turning fortunes, see Curran, 88, and Brawley et al., Competing Voices, 71-2. On Curtin-Churchill disagreements, see Day, 'John Curtin-In Office'.

46 Gilmore, Singapore. On rationing in Australia, see Bongiorno and Dyrenfurth, A Little History of the Australian Labor Party, 96.

47 On the history of ideas behind the breaking-up of larger squatters' runs, see Richard Waterhouse, 'Agrarian Ideals and Pastoral Realities: The Use and Misuse of Land in Rural Australia', in Great Mistakes of Australian History, ed. Martin G. Crotty and David A. Roberts (Sydney: UNSW Press, 2006), 67, 69; and on closer settlement (the acquisition and subdivision of those large estates), see 70; on sheep, see Charles Massey, The Australian Merino (Ringwood, Vic.: Viking O'Neil, 1990).
} 
1901 Western Lands Act limiting the number of sheep that could he held on a property. Such an amendment did not occur until after the drought, in 1949. ${ }^{48}$ This encouraged overstocking of small blocks in good years, which is exactly what happened in the years leading up to the World War II droughts, when stock levels were the highest ever recorded. ${ }^{49}$ When drought came, properties became overcrowded with sheep, native shrubs were eaten out, and dry topsoils were then exposed to the wind. The effects for sheep and other domesticated animals, for the soil, for saltbush, and for graziers were equally devastating. Seventy per cent of the sheep in the western Riverina - at least 1 million - had died by 1944. Graziers naturally were not solely responsible for all of this. ${ }^{50}$ As described above, they were caught within a complex interplay of elements contributing to erosion, from inadequate transportation to acute wartime manpower shortages and plague-level rabbits. ${ }^{51}$

Despite this, filmmakers, broadcasters and the press laid various measures of blame on the grazier and his lack of 'conservation mindedness'. In Australia is Developing a Dust Bowl and Drought Grips Riverina, Ken Hall reflected this view by using imagery suggesting that graziers who overstocked their land were to blame, at least in part, for Australia 'developing a dust bowl' ${ }^{52}$ Rather than as a symbol of economic progress, he portrayed sheep as 'trampling across the face of Australia'. ${ }^{53}$

With the south-east suffering under severe drought and erosion conditions, Hall was also able to draw on the power of irrigation myth - that dream of transforming arid and semi-arid lands into green garden oases. ${ }^{54}$ Australia is Developing a Dust Bowl was a propaganda film that told a national story of decline and later progress with the intention of promoting the national

48 On the history of Western Lands legislation and leasehold arrangements, see Janice Cooper, 'Land as Property or Natural Resource: The Western Lands Act of 1901-1910', History Australia 10, no. 3 (December 2013), particularly 205. On drought conditions and overstocking in the late nineteenth century, see Christine Adams, Way out West (Joondalup, WA: Ocean Publishing, 2008), vi; see also Tom Griffiths, 'One Hundred Years of Environmental Crisis', Rangeland Journal 23, no. 1 (2001); Deb Verhoeven, Sheep and the Australian Cinema (Melbourne: Melbourne University Press, 2006).

49 McTainsh et al., Wind Erosion, 21.

50 On stock routes and transport needs, see Cooper, 'Land as Property or Natural Resource', 210; on the 1949 clause, see 194; on the 1901 Western Lands Act, see 205; on drought relief, see McTainsh et al., Wind Erosion, 26; on the formation of soil agencies, see 19; on the combination of overstocking, drought, and wind, see 20; see also 21; on closer settlement, see Waterhouse, 'Agrarian Ideals and Pastoral Realities', 67, 69, 70; on the issue of contributors, see Barr and Cary, Greening a Brown Land, 112.

51 On record high pre-drought stock levels, see McTainsh et al., Wind Erosion, 21; on rabbits, see Thomas Dunlap, 'Ecology and Environmentalism in the Anglo Settler Colonies', in Ecology and Empire: Environmental History of Settler Societies, ed. Tom Griffiths and Libby Robin (Carlton South, Vic.: Melbourne University Press, 1997), 79. On a complex interplay of contributors, see Barr and Cary, Greening a Brown Land, 112.

52 Cinesound Productions, Australia is Developing a Dust Bowl.

53 George Farwell, 'William Hatfield sees ... the "Vision Splendid" For Australia', The Guardian, 17 November 1944.

54 On the irrigation dream, see Tyrrell, True Gardens of the Gods, 110; also 107-8, 111, 112, 113, 133, 140. 
conservation vision shared by the New South Wales state and Commonwealth Labour governments under McKell and Curtin. However, Hall used transnationalism as a storytelling strategy to sell an Australian nationalistic message, in doing so drawing on a variety of compelling ideas, in addition to wartime sentiment, Australia's sheep myth, and Australia's irrigation dreams in his conservation narrative.

As Australians further entered drought, fears of invasion, of existing desert going to waste, were combined with perceptions of an 'end' to the US Dust Bowl and dreams of watering and powering arid lands with US-style, large-scale engineering schemes. ${ }^{55}$ In Australia is Developing a Dust Bowl, Hall drew on wartime drought sentiment by evoking the Dust Bowl, a US national narrative, which he laced with traces of New Deal rhetoric. ${ }^{56}$ Hall's narrative, like others at the time, suggested that the scientific expert and conservation farmer were patriots, as opposed to those who neglected the soil while Australians were dying on foreign soil to save it. Hall did all of this to portray the idea of drought and erosion as a threat to the nation.

US Dust Bowl narratives described a place, a time, and a phenomenon - wind erosion of the 1930s on the southern Great Plains in south-eastern Colorado, north-eastern New Mexico, the northern two-thirds of the Texas panhandle, the western third of Kansas, and the Oklahoma panhandle. ${ }^{57}$ But it was also a powerful idea that developed during a decade of drought and Depression and generated a huge collection of widely published and enduring imagery. This imagery described not only wind erosion on the southern Plains, but also drought beyond that region, water erosion, and soil infertility, and their effects through animal suffering and death, displacement, and poverty. This kind of Dust Bowl imagery had currency at the time in the US. It also found resonance in the following decade in Australia, and Ken Hall capitalised on this.

\footnotetext{
55 The Bank of New South Wales tried to expose this myth in 'Australia's Vast Empty Spaces', The Western Australian Bank and the Australian Bank of Commerce Limited Circular VI, no. 5 (August 1936).

56 On the Dust Bowl as national narrative, see Gordon, Dorothea Lange: A Life Beyond Limits, 244. On the Dust Bowl as an event of 'mythological proportions' that was 'defined by artists and by government bureaucrats', see Geoff Cunfer, What Was 'The Dust Bowl'? (2010), eh.net/encyclopedia/the-dust-bowl/; on Cunfer's perspective, the connections to James C. Malin, and Dust Bowl narratives in the US historiography, see William Cronon, 'A Place for Stories', 1347-76; on New Deal influences in the Australian context, see also Bailey, “'Dust bowls", TVAs and Snowy River waters' and Dust Bowl: Depression America to World War Two Australia.

57 On the location of the Dust Bowl, see Donald Worster, Dust bowl: The Southern Plains in the 1930s (New York: Oxford University Press, 1979), 12; and see 28-9; on dust storms beyond these borders, see 13; and on drought conditions across the US, see 11 .
} 
Water conservation imagery also had value. An image of water falling over the perfectly designed sections of a massive dam spillway expressed the optimism of an age associated with high modernism, and could certainly be used to peddle visions of a utopian postwar world. Hall was aware of this. To further empower his storytelling, in Australia is Developing a Dust Bowl, he took inspiration from a second aspect of the American story, evoking the dam-building achievements of the US Bureau of Reclamation (1902) in the American West and the TVA in the east. In reality, neither agency applied large-scale engineering projects as a remedy to the US Dust Bowl, while the TVA was in a different region altogether. Australian political and environmental conditions, such as rainfall, differed to those in the east and west of the USA, where these American agencies had established their projects. ${ }^{58}$ But Australian storytellers such as Ken Hall drew on the powerful reputations of these engineering projects nonetheless, and in Australian wartime narratives, enormous dams became associated with salvation from 'dust bowls'. Imagery promoting water conservation schemes in New South Wales, Victoria, and Queensland used the threat of a 'dust bowl' to promote their desired schemes, a very different set of imagery to that describing the US Dust Bowl.

In Australia is Developing a Dust Bowl, US references were designed to boost New South Wales' nation-building credentials in debate over the most suitable postwar water conservation scheme. Hall's use of dam imagery stretched the truth about the US Bureau of Reclamation's projects and water conservation by suggesting that large-scale engineering projects had been the solution to the Dust Bowl on the southern Great Plains, even though they had not. Ignoring reality, then, he inferred that they would also be the solution to drought and wind erosion problems plaguing the more arid western New South Wales Riverina region. ${ }^{59}$ The way to achieve such a parallel solution in Australia, the film suggested, was to look to the credentials of New South Wales - it had

58 For details of TVA influences in Australia (with some reference to international influences), see Bailey, Dust Bowl: Depression America to World War Two Australia.

59 On water conservation strategy for the Great Plains, see Morris Llewellyn Cooke, The Future of the Great Plains: Report of the Great Plains Committee (Washington DC: G.P.O., Great Plains Committee, 1936), 76-7; in his Land of the Underground Rain: Irrigation on the Texas High Plains 1910-1970 (Austin, TX: University of Texas Press, 1973), 134-5, Donald E. Green discusses water facilities legislation that provided only for 'the installation of pumping plants', and even then, did not even specifically mention them. See also Worster, Dust Bowl, 252-3. 
already built the Burrinjuck Dam on the Murrumbidgee by $1928 .{ }^{60}$ Hall drew parallels between New South Wales, its potential to expand on the achievement of Burrinjuck Dam, and federal government dam-building achievements in the USA. He did this to promote the viability of a Commonwealth governmentbacked nation-building scheme that would expand the MIA. There was also a promise of postwar employment built into this water conservation imagery, which linked to Labour's goal of full employment and the promise of an enormous population of settlers thriving on all that diverted Snowy River water (Map 2).

Australia is Developing a Dust Bowl reflects a broader set of ideas that were being dramatised more widely in the print, film, and broadcast media of the decade. For example, transnational imagery promoting a national scheme appeared in newspaper articles supporting the work of Australian documentary filmmaker John Heyer, who promoted a rival Victorian water diversion scheme later in the decade for the Murray River. ${ }^{61}$ They materialised in newspaper articles about the Murrumbidgee Valley Water Users' Association (MVWUA, established 1939), which supported the MIA scheme and appeared in books by the popular author Ion L. Idriess, the Queensland water conservation advocate Fred Timbury, and the activist Michael Sawtell. ${ }^{62}$ Their Queensland vison was one that tried to out-compete New South Wales by promoting the Bradfield/ Idriess scheme, based on the 1938 Bradfield Plan for Watering Inland Australia. They frequently conjured the threat of a 'dust bowl' moving east across the continent from Lake Eyre and contrasted this against what gigantic dams modelled on the projects of the US Bureau of Reclamation could do to counter it. Speaking at a Millions Club luncheon in Sydney, Idriess argued that a major water diversion scheme was needed to open up the interior for settlement

60 Under expert guidance from Elwood Mead. On Mead, see Tyrrell, True Gardens of the Gods, 159; on the establishment of the MIA, see B. R. Davidson, Australia, Wet or Dry? The Physical and Economic Limits to the Expansion of Irrigation (Melbourne: Melbourne University Press, 1969), 68-9; on Burrinjuck Dam or 'Barren Jack Dam and Murrumbidgee Canals construction' [1906], see 68-9; Emily O'Gorman in her Flood Country (Melbourne: CSIRO Publishing, 2012), 47, describes the effect of the Burrinjuck Dam on Murrumbidgee River hydrology. On earlier water conservation initiatives in south-eastern Australia, including the Hume Dam (1936) on the Upper Murray River, see Australian Government, Murray Darling Basin Authority, 'Hume Dam' (2015), www.mdba.gov.au/river-information/running-river-murray/hume-dam. The Hume Dam was enlarged in 1954 to allow for water diverted by the Snowy Mountains Scheme.

61 On Heyer and transnational imagery used to promote the Victorian rival scheme for a "TVA for the Murray River', see Bailey, “'Dust bowls", TVAs and Snowy River waters' and Dust Bowl: Depression America to World War Two Australia.

62 The writer has not located a direct link between the creation of Hall's film and the MVWUA; however, the Association may have indirectly influenced the creation of the film. This occurred in the parallel Victorian case where their later rival scheme calling for a TVA for the Murray was backed by the Murray Valley Development League, which under G. Vernon Lawrence pushed the Australian National Film Board in the Department of Information to produce John Heyer's The Valley is Ours (1948). See Bailey, "“Dust bowls", TVAs and Snowy River waters' and Dust Bowl: Depression America to World War Two Australia. 
of thousands of people, make the 'dead heart' of Australia blossom like a garden, kill the 'dust bowl' of Australia, which had already reached the Darling River, and check the onslaught of drought in western New South Wales. ${ }^{63}$

This set of ideas drawn from US and Australian narratives was dramatised in imagery circulated by newspapers such as the Melbourne Argus and in the Sydney Morning Herald. In the Sydney Morning Herald in 1944, a columnist (writing under the name of a New South Wales flower, 'Waratah') argued that Burrinjuck Dam in New South Wales was already a 'shining dual purpose example'. ${ }^{64}$ Surely, he believed, 'the great Boulder, Coulee and the two Tennessee Valley dams' would inspire support for a scheme that would further irrigate western New South Wales. ${ }^{65}$ This kind of US/Australian imagery was also circulated by the Australian Broadcasting Commission's ${ }^{66}$ Nation's Forum of the Air; by Cinesound in films such as Conserve Water; in journals such as Australasian Engineer; and even by the Australian Women's Weekly. When it featured in an article by retired public works architect A. J. Macdonald on 'Australia's greatest internal question', Australasian Engineer included images of US dams to 'stress the importance of water conservation to Australia' ${ }^{67}$ To illustrate the need for 'souls that do or dare' (brave men risking their lives on dangerous dam-building projects), nine photographs were reproduced, of the Shasta, Coulee, and Friant

63 First published much earlier, in 1938, the Bradfield Scheme was designed by Australian civil engineer J. J. Bradfield and outlined in a 1941 issue of Rydges Weekly. It aimed to capture the waters of northern Queensland rivers that flowed into the sea, and turn them inland across the Great Dividing Range. See Commonwealth Meteorological Bureau, Bradfield Scheme for Watering the Inland: Meteorological Aspects, Bulletin no. 34 (Melbourne: Government Printer, 1945); 'The Bradfield Scheme', Journal of the Royal Australian Historical Society 95, no. 1 (June 2009): 38-51; the name of the Millions Club reflected the club's goals to increase both population and immigration. For the Millions Club quotation, see Ion Idriess, Ambitious Plan: Converting Desert into Garden-Irrigation Scheme for Central Australia', Sydney Morning Herald, 21 November 1944. Also see Idriess' story in 'Ambitious Plan: Converting Desert into Garden-Irrigation Scheme for Central Australia', Canberra Times, 21 May 1941; Fred R. V. Timbury, 'Australia's Future Depends on Battle for the Interior', Daily Mirror, 17 January 1945; Fred R. V. Timbury, Battle for the Inland (Sydney: Angus and Robertson, 1944); Ion L. Idriess, Onward Australia: Developing a Continent (Sydney: Angus and Robertson, 1944) and The Great Boomerang (London: Angus and Robertson, 1941); Jill Roe, 'Sawtell, Olaf (Michael) (18831971)', Australian Dictionary of Biography, adb.anu.edu.au/biography/sawtell-olaf-michael-13186/text23871; Cathcart, The Water Dreamers, 237; J. M. Powell, Plains of Promise, Rivers of Destiny: Water Management and the Development of Queensland 1824-1990 (Bowen Hills, Qld.: Boolarong Publications, 1991), 161; Robert Wooding, 'Populate Parch and Panic: Two Centuries of Dreaming about Nation Building', in Australia Under Construction, ed. John Butcher (Canberra: ANU E Press, 2008), 66, press-files.anu.edu.au/downloads/press/ p118181/pdf/ch069.pdf; Andrew Gillanders in 'Mirage of the Inland Sea: The Bradfield Scheme', Journal of the Royal Australian Historical Society 95, no. 1 (June 2009): 38-51, notes the scheme was conceived at the same time as the Snowy scheme.

64 The waratah, Telopea speciosissima, was proclaimed the official floral emblem of New South Wales on 24 October 1962. 'Waratah' is the Aboriginal name for the species, adopted by early Sydney Harbour settlers. See Australian National Herbarium, 'Floral Emblems of New South Wales' (Australian National Botanic Gardens and Centre for Australian National Biodiversity Research, Canberra), www.anbg.gov.au/emblems/ nsw.emblem.html.

65 Waratah, 'Irrigation is our Major Need', Sydney Morning Herald, 29 September 1944.

66 Formerly the Australian Broadcasting Company, now the Australian Broadcasting Corporation.

67 And at the time, to suggest a Mountain Lake in Canberra as a possible solution. 
Dams. ${ }^{68}$ Macdonald reiterated this appeal in 1945, calling for a national water conservation scheme. ${ }^{69}$ Without it, he warned, the Murray River Basin on New South Wales' southern border would be 'gripped with water famine, to become a sunburnt, sand-blown wilderness strewn with the bleached bones of dumb animals, bearing silent testimony to economic ruin'.$^{70}$ Macdonald promoted both US engineering possibilities and this dust bowl imagery to argue that 'the waters of the Snowy River should be diverted'. ${ }^{71}$ In this, he was far from being alone.

Despite the fusing of this set of US and Australian ideas in the transnational imagery employed by Hall, the filmmaker has been described as a 'brilliant propagandist', his films strongly nationalistic and exhibiting 'a palpable love of rural Australia and the environment' ${ }^{72}$ Unlike films made by Movietone, Cinesound's are said never to have used an imported story, while all their content was created by Australians. ${ }^{73}$ However, Hall modelled the narrative structure of Cinesound films on the techniques of the Hollywood studio system. And although Australia is Developing a Dust Bowl is full of both textual and visual US references, Hall was expressing a nationalist Australian perspective. Australian historian Frank Bongiorno has described this in his recent discussions of 1940s politics, arguing that 'there was more than one way of being nationalist'.$^{74}$ Like many of his contemporaries, including Australian international documentary filmmaker John Heyer, Hall used transnationalism as a storytelling strategy. ${ }^{75}$

68 Shasta Dam is in Central Valley, California, and served northern Californian war plants. The Grand Coulee Dam, in eastern Washington, served the Columbia Basin and Pacific North-West industry. Friant Dam was an irrigation dam serving the San Joaquin Valley, California, and all were projects of the US Bureau of Reclamation; on the transformation of the Columbia River and US water conservation ideas, see White, The Organic Machine.

69 On Macdonald's career, see Anne Neale, 'A. J. Macdonald: Enigma and Romance in the Public Service', Fabrications 10, no. 1 (August 1999): 115-35; Diane Firth, 'A Mountain Lake for Canberra', The National Library Magazine (June 2013): 18.

70 A. J. Macdonald, 'Canberra and Water Power: A Plea for the Mountain Lake - Illustrated with American Dams to stress the importance of water conservation', Australasian Engineer, Yearbook (November 1944): 7. Macdonald submitted this article to the Rural Reconstruction Commission. See A. J. Macdonald, Elsternwick, Melbourne, to Prime Minister John Curtin, 10 April 1945 (P.M. File No. A.423/1/2), Rural Reconstruction Commission - Snowy River Electric Scheme - representation on behalf of municipalities and organizations, National Archives of Australia, series A9816, item 1944/485. W. G. Tweedie of Ivanhoe responded to Macdonald in a letter to the editor in which he referred to a report by the Sydney division of the Institution of Engineers that Victorian Premier Albert Dunstan had questioned in 'Diverting the Snowy River', Argus [Melbourne], 28 February 1945. See also A. J. Macdonald, 'Diverting the Snowy River' [letter to the editor], Argus, 19 February 1945. Macdonald attacked Dunstan and the Victorian Country Party for their lack of support for a water scheme.

71 Macdonald, 'Diverting the Snowy River'.

72 Ray Edmondson, email to author, 6 August 2012.

73 Edmondson, 'The Voice of Australia', 2.

74 Frank Bongiorno, 'Comment: Australia, nationalism and transnationalism', History Australia 10, no. 3 (December 2013): 81.

75 John Heyer's The Valley is Ours (1948) was a propaganda film supporting the rival water conservation scheme planned by the state of Victoria and the Murray Valley Development League. For an in-depth analysis of Heyer's use of transnationalism as a storytelling strategy in The Valley is Ours, see Bailey, "'Dust bowls", TVAs and Snowy River waters' and Dust Bowl: Depression America to World War Two Australia. 
Hall loaded his films with American referents to help him to pose a question for his audience. Using imagery contrasting dams against 'dust bowls', he promoted the New South Wales scheme and strengthened a nationalistic message about the Australian environment. But most importantly, what Hall's imagery and that of Idriess, Macdonald, Heyer, and others did was to understand and tap into the fears, hopes, and dreams they knew to be playing out in the minds of their wartime audience. Hall's contrasting imagery challenged Australians by asking what kind of postwar future they really wanted. Did they want to live in a US-inspired modern utopia that the New South Wales Government could readily provide by expanding on the existing achievement of Burrinjuck Dam? Or would they prefer a bleak future of US-style 'dust bowls', bringing drought and wind erosion that would eventually lead to sheep, and even human, extinction? Contrasted against such a powerful symbol of modernity in the form of the dam, Hall's portrayal of a 'developing dust bowl' only accentuated the meaning of large-scale engineering projects and what, with Snowy River water, one ambitious state could do for the nation. ${ }^{76}$

\section{Noel Beadle, sand, saltbush, sheep, and a model dam}

Despite Hall's significant reputation, the films discussed here are not widely remembered, even by cultural and environmental historians. This might be related to the fact that Australia is Developing a Dust Bowl reflects some of the many questions being raised in its time over the quality of Australian films. At a 1941 conference of Commonwealth and state governments on the non-theatrical exhibition of films, attendees expressed the concern that if Australian films had a message, it was 'not dramatized enough or projected sufficiently clearly'. Audiences felt there were 'too many pictures' in the films. They meant that the editor was cutting from one image to the next too often, too suddenly, and without explanation. ${ }^{77}$ Reflecting such issues, the Cinesound films discussed here often jump suddenly to and from one image - that of a dam - without explanation. From a transnational research perspective, however, this technical awkwardness is illuminating. Rather than presenting a seamless integration of ideas, it clearly highlights Hall's attempts to connect US-inspired ideas about dams to US-inspired ideas about 'dust bowls' - and give that connection an Australian meaning. The out-of-place appearance of the dam image is what inspired this research project to trace the set of ideas and set of circumstances giving rise to its clumsy appearance in Hall's film. The single image of a dam used by Hall was of a scaled-down

76 Cinesound Productions, Australia is Developing a Dust Bowl.

77 Agenda for conference between Commonwealth and state governments on non-theatrical exhibition of films, held at the State Lands Department Sydney, Wednesday 26th March, 1941, 35. National Archives 
reproduction of the Woronora Dam (built between 1927 and 1941) that services southern Sydney, far from the Riverina. ${ }^{78}$ This image appeared in a number of Cinesound newsreel or documentary films about soil erosion. The model dam was built for National Productions Limited in a 'rented space on the lot of the closed down Pagewood Studios' in Sydney so that it could be blown up in the feature comedy, Dad Rudd M.P. (released in 1940), the last film Cinesound were able to make before World War II (Figure 2). ${ }^{79}$

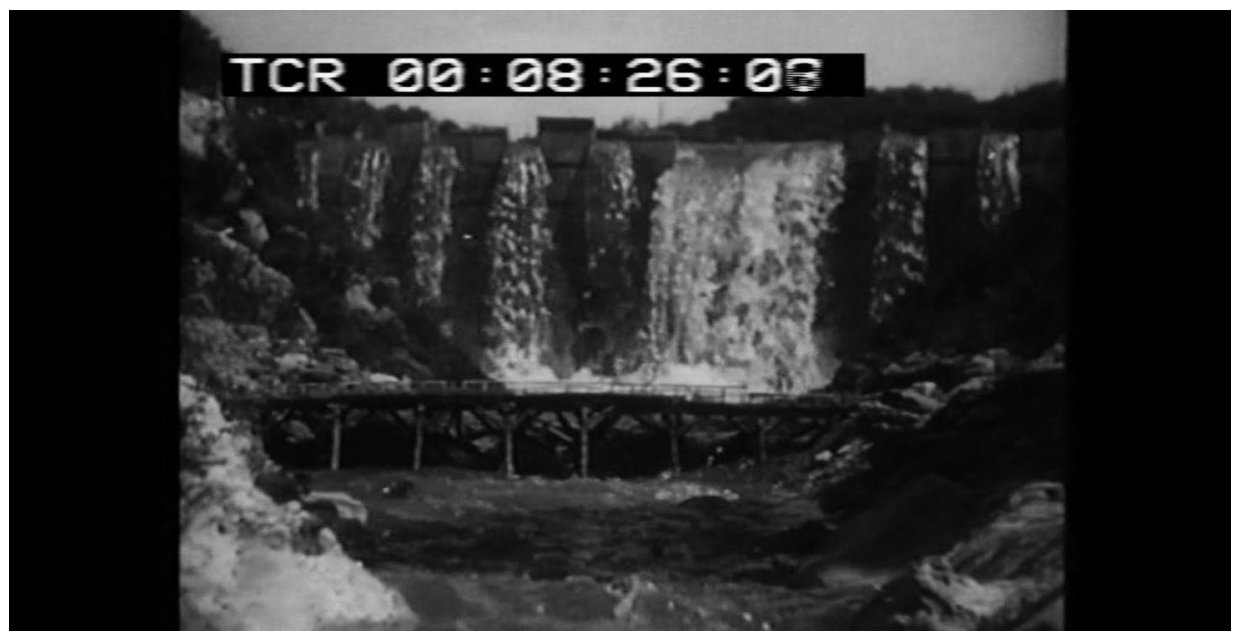

Figure 2: An expression of the optimism of the age associated with high modernism, and visons of a utopian postwar world. Ken Hall's model of Woronora Dam as seen in Cinesound Productions, Australia is Developing a Dust Bowl (1943).

Source: Cinesound Productions, Australia is Developing a Dust Bowl (1943), National Film and Sound Archive.

War, however, did not mean an end to all filmmaking. Rather, it facilitated the development of a documentary movement, first established in the 1930s and Australian Government film propaganda proliferated and developed ${ }^{80}$ During the process, motion picture footage such as Hall's dam sequence was often cut and pasted into Australian newsreel or 'documentary' films. This accounts for the rather out-of-place and often sudden appearance of Hall's dam in various newsreel films. In Australia is Developing a Dust Bowl and Conserve Water,

78 Woronora Dam was built between 1927 and 1941 to service metropolitan Sydney up to 1960, and is the last of five water supply dams built prior to World War II. New South Wales Government Office of Environment and Heritage, 'Heritage sites: Woronora Dam' (updated 10 September 2009), www.environment. nsw.gov.au/heritageapp/ViewHeritageItemDetails.aspx?ID=5051466.

79 Ken Hall built this model dam to create 'a tremendous action climax of the flooding and destruction of the dam - a remarkable technical achievement for this country', in Dad Rudd M.P. See Hall, Directed by Ken G. Hall, 155. See 155-6 for details of the model's construction. For the national symbolism of the dam in Dad Rudd M.P., see Michael Cathcart, The Water Dreamers, 235; on location film footage being edited into newsreels, see Helen Ennis, Exposures: Photography and Australia (London: Reaktion, 2007), 91.

80 See Ina Bertrand and Diane Collins, Government and Film in Australia (Sydney: Currency Press, 1981). 
the model dam conveyed a political message. ${ }^{81}$ It reflected Commonwealth government attempts to extend their constitutional powers over soil and water conservation. And it reflected New South Wales' determination to control any national water scheme that ensued. At a 1942 Constitutional Convention, the states unanimously agreed to pass legislation that would transfer powers to the Commonwealth. ${ }^{82}$ The aim was to avoid a referendum in wartime. ${ }^{83}$ But the corresponding legislation needed was not successfully passed by all the states, due to a political tactic employed by Victorian premier Albert Dunstan ${ }^{84}$ that forced the Commonwealth to consider achieving their aims via a referendum. ${ }^{85}$ These plans were postponed due to Curtin's fear of losing favour at an impending federal election. ${ }^{86}$ They were also complicated by an impending trip to Washington and London and by his return, which came against the whole atmosphere of the June 1944 Normandy landings. '[T]he greatest amphibious operation of all time' and 'the beginning of the end of Nazi tyranny in Europe' was not an ideal time to call Australians to a referendum. ${ }^{87}$

Soil and water conservation were not the only issues under consideration at the August 1944 referendum. Had it been a success, however, the Commonwealth government might have seen soil and water conservation transferred from the

81 Conserve Water is undated. For an analysis of this film, see Bailey, Dust Bowl: Depression America to World War Two Australia.

82 On the Constitutional Convention, see also Bailey, Dust Bowl: Depression America to World War Two Australia; Macintyre, Australia's Boldest Experiment, 254. On the exclusion of women from the Convention, see Macintyre, 'Women's Leadership in War and Reconstruction', 75 and Australia's Boldest Experiment, 137. 83 For discussion of how 'uniform laws' were needed, particularly for New South Wales and Victoria, see Con Hartnett, Curtin and McKell, Architects of Regionalism in Australia, interim ed. (Tighes Hill, NSW: Hunter Valley Research Foundation, 1984), 61. On expanding constitutional powers, see Bongiorno and Dyrenfurth, A Little History of the Australian Labor Party, 98-9.

84 On Dunstan's politics and his lack of support for soil conservation in his state of Victoria, including his evasion of the whole issue of the US Dust Bowl and its relevance to Australia, see Bailey, Dust Bowl: Depression America to World War Two Australia.

85 In 1948, Keith O. Campbell noted the 'peculiar appeal' for the general public that made 'conservation' a useful tool for political propaganda: 'The Development of Soil Conservation Programmes in Australia', Land Economics 24, no. 1 (February 1948): 67; the first reading of the 1942 War Aims and Reconstruction Bill (Commonwealth) (or Constitution Alteration Bill) occurred in the Commonwealth Parliament House of Representatives on 1 October 1942. The Attorney-General, Dr H. V. Evatt, did not hesitate to quote the four essential human freedoms from President Roosevelt's Atlantic Charter in order to promote change in Australia, according to Brian Galligan, A Federal Republic: Australia's Constitutional System of Government (Melbourne: Cambridge University Press, 1995), 144; W. J. Waters, 'Australian Labor's Full Employment Objective', 49; on the 1942 War Aims and Reconstruction Bill, see also Macintyre, 'Women's Leadership in War and Reconstruction', 72 and Australia's Boldest Experiment, 137-8.

86 Macintyre, Australia's Boldest Experiment, 254.

87 Hartnett, Curtin and McKell, 62, 64; Commonwealth Government of Australia, You and the referendum (Canberra: Commonwealth Government of Australia, 1944). see also Bailey, Dust Bowl: Depression America to World War Two Australia; on public interest in a referendum see 140-1; on the media publicity campaign see 259-61; and on the timing of the referendum, delayed until 1944, see Macintyre, 'Women's Leadership in War and Reconstruction', 74 and Australia's Boldest Experiment, 141, 258. 
states into their hands. ${ }^{88}$ However, the referendum failed. In continued pursuit of their conservation vision, the Department of Information screened Hall's Australia is Developing a Dust Bowl to Premier McKell and members of the state government at Film House, Canberra, in November 1944 at the height of the drought. ${ }^{89}$ A second screening took place one week later for a private audience of federal parliamentarians and officials, as dust storms swept across the south-east. Crayton Burns reported for the Melbourne Argus that, combined with the screenings, the blanket of dust sweeping across Canberra was giving Labour parliamentarians a 'lesson' in the realities of wind erosion. He described the hot, dry conditions and heavy dust pall prevailing across the capital. This, he said, created a potent 'atmosphere' that accentuated the meaning of this 'grim visual demonstration' for its audience. ${ }^{90}$ What did this 'grim visual demonstration' look like?

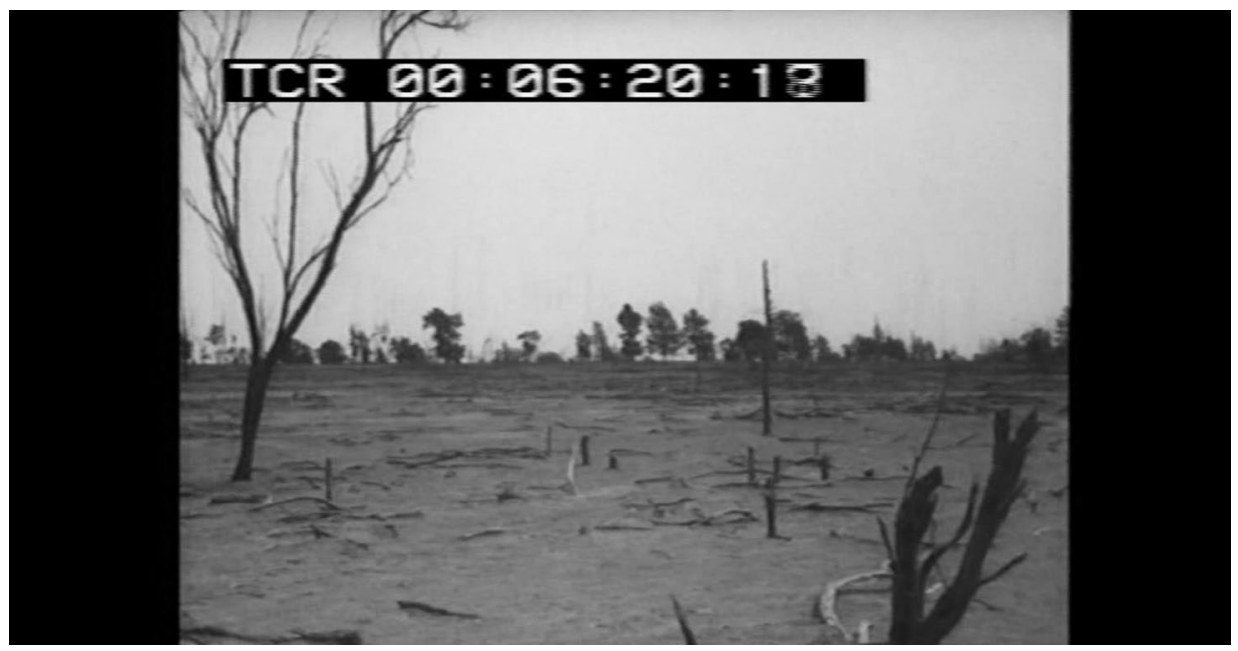

Figure 3: A dramatic cinematic score creates a sense of unease and impending disaster. 'That was a crop in the drought area. Now it is part of a potential dust bowl. Wind whips the surface soil away from the stunted crop.' This imagery suggests salvation is urgently needed for the nation's Riverina food bowl if a 'dust bowl' is to be prevented: opening scenes from Australia is Developing a Dust Bowl.

Source: Cinesound Productions, Australia is Developing a Dust Bowl (1943), National Film and Sound Archive.

88 Commonwealth Government of Australia, You and the referendum. In 1944, Leslie Haylen (mentioned above as the Member for Parkes) was the publicity officer for the 'fourteen powers' referendum. See R. E. Northey, 'Haylen, Leslie Clement (Les) (1898-1977)', Australian Dictionary of Biography, adb.anu.edu.au/ biography/haylen-leslie-clement-les-10466/text18565.

89 This screening was reported on in 'No Fodder Reserves Available[;] Relief Likely in Summer', Sydney Morning Herald, 8 November 1944.

90 Crayton Burns, 'Conference Urged on Erosion', Argus, 17 November 1944. On 'lessons' and grim visuals, see Burns, 'MPs Warned of Dust Bowl Danger'. Conditions were described in 'Heat and Dust in Sydney', Argus, 14 November 1944, using reports by NSW Divisional Meteorologist David Mares. 


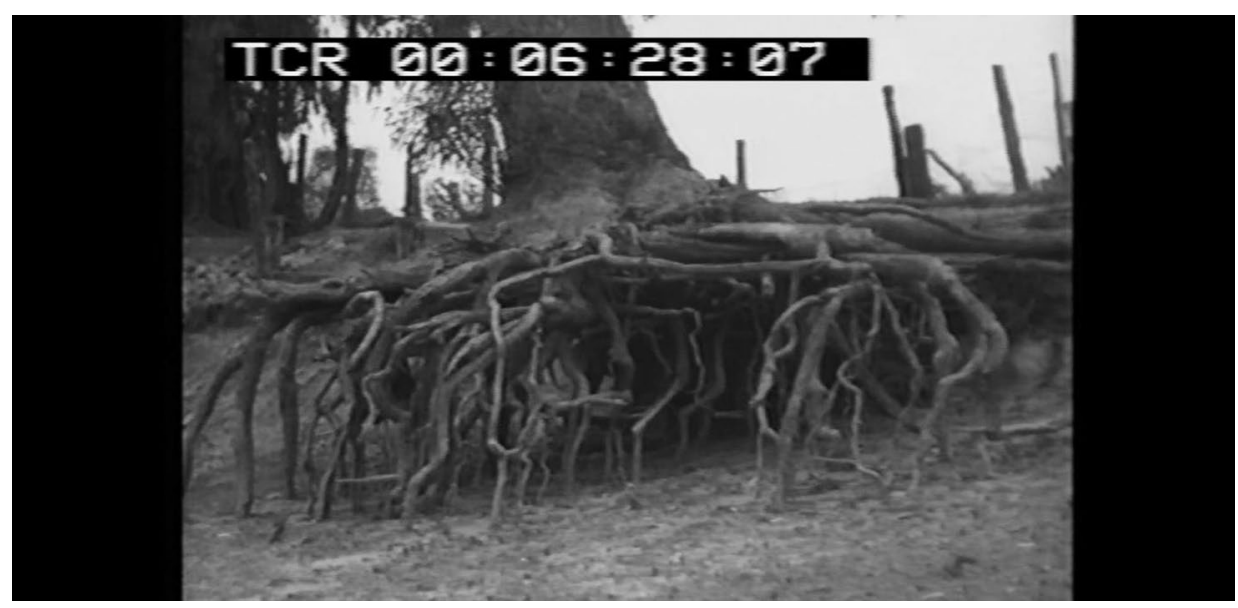

Figure 4: Images of wind having blown surface soil away are evidence of a 'dust bowl' threat.

Source: Cinesound Productions, Australia is Developing a Dust Bowl (1943), National Film and Sound Archive.

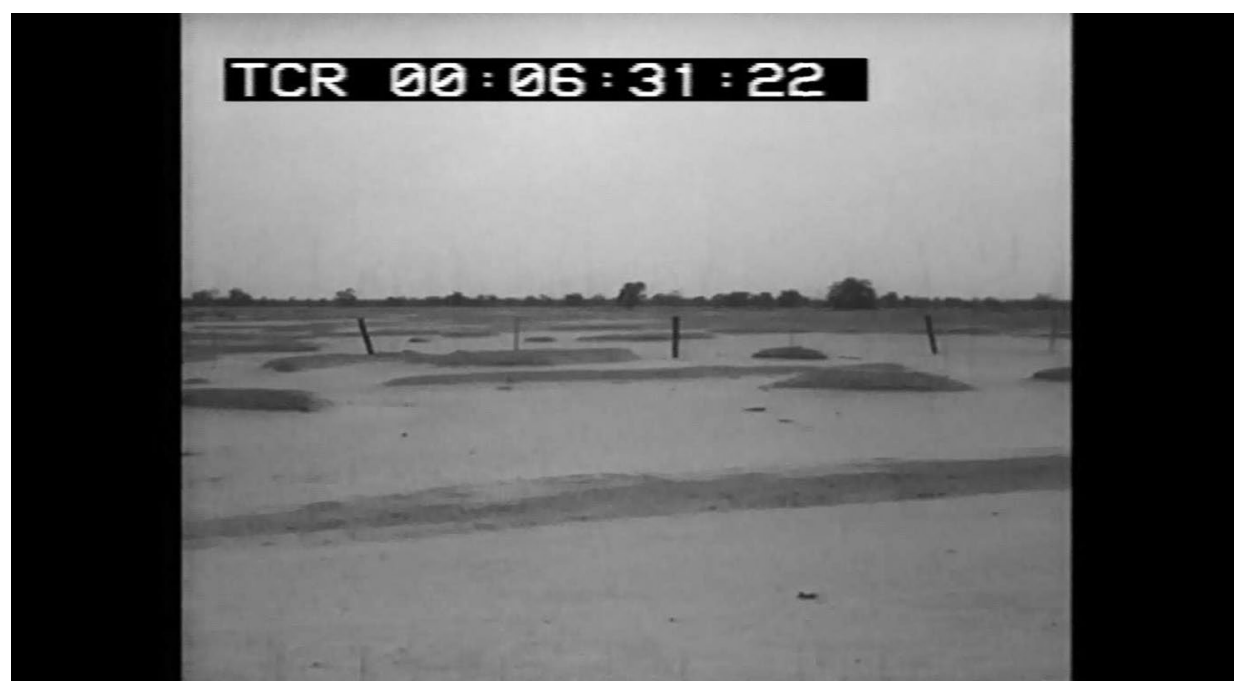

Figure 5: 'Most of the surface soil gone, leaving small oases. They will go too.' Ken Hall's imagery both feeds on and reflects the 'dust bowl' fears of the time as expressed across different media.

Source: Cinesound Productions, Australia is Developing a Dust Bowl (1943), National Film and Sound Archive. 


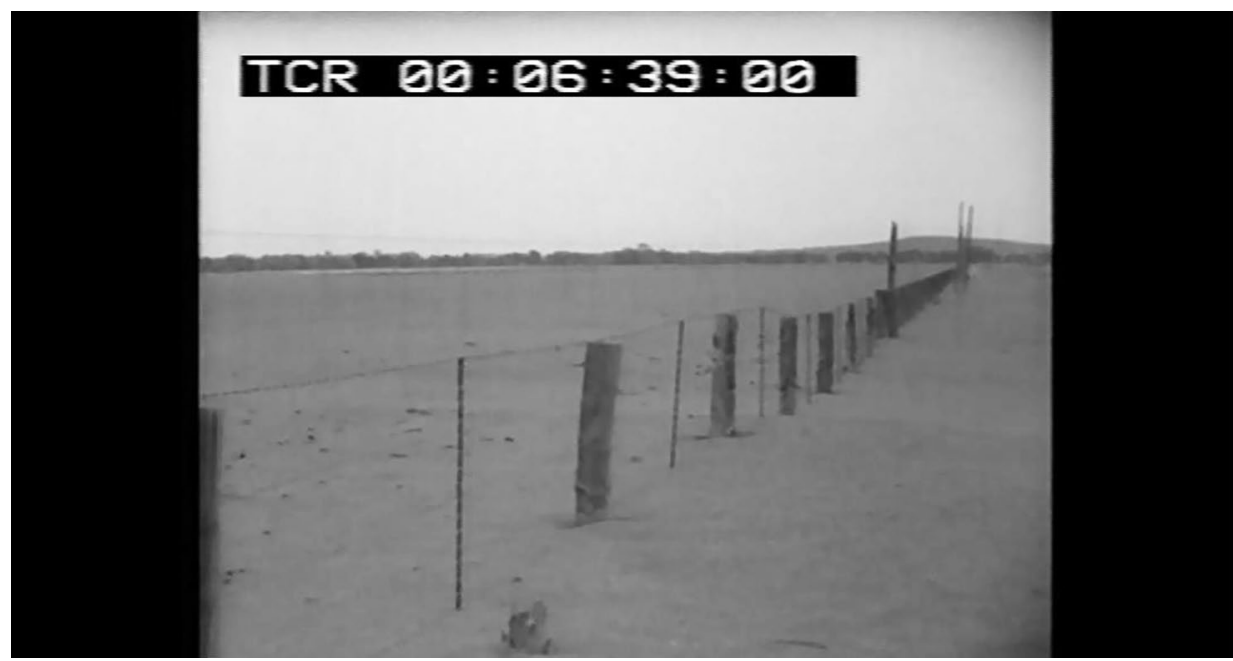

Figure 6: 'Farmlands are literally blowing away and the subsoil that is left is comparatively valueless.' This imagery suggests that unless conservation action is taken, the Riverina will become a sandy desert.

Source: Cinesound Productions, Australia is Developing a Dust Bowl (1943), National Film and Sound Archive.

Australia is Developing a Dust Bowl opens with a warning: 'that was a crop in the drought area. Now it is part of a potential dust bowl.' Narrator Peter Bathurst further warns us that 'Farmlands are literally blowing away' (Figures 3-6). ${ }^{91}$ The film cuts to Condobolin Government Station. Here we see the pioneering work of Noel Beadle on his vegetation regeneration project for the New South Wales Soil Conservation Service (Figure 7). During the 1940s, Beadle produced the first coherent classification and map of the vegetation of western New South Wales. He was the first person ever employed by the Soil Conservation Service to conduct such a survey of western New South Wales. His work was frequently cited by contemporaries such as the economic geographer Arthur G. Lowndes, whose thousands of photographs and notes documented soil erosion conditions on farms and stations across the continent for the Bank of New South Wales. ${ }^{92}$

91 Cinesound Productions, Australia is Developing a Dust Bowl; on the British actor, see Imdb, 'Peter Bathurst: Biography' (2014), www.imdb.com/name/nm0061105/bio?ref_=nm_ov_bio_sm, accessed 2 February 2014.

92 Bank of New South Wales economic geographer Arthur G. Lowndes travelled widely overseas, created transnational publications, and travelled across Australia undertaking surveys of soil erosion in every state: see Bailey, Dust Bowl: Depression America to World War Two Australia. The fruits of his efforts included thousands of photographs as well as numerous references to the work of contemporaries Noel Beadle and Francis Ratcliffe. See C. V. Janes and A. G. Lowndes for the Bank of New South Wales, Photographs of Soil Erosion, c. 1936-56, State Library of New South Wales, PXE 1257; Strathfield Council, 'Strathfield Heritage: all about the history and heritage of Strathfield. Arthur Lowndes-Arthur George LOWNDES CBE, M.Sc. (1911-1994)', strathfieldheritage.org/local-government/council/mayors-of-strathfield-council/arthur-lowndes/. 
Beadle's research is considered today a benchmark study in the field.${ }^{93} \mathrm{He}$ was able to continue this work throughout the war because Soil Conservation Service director Sam Clayton, a World War I veteran himself, would not allow his soil men to enlist.

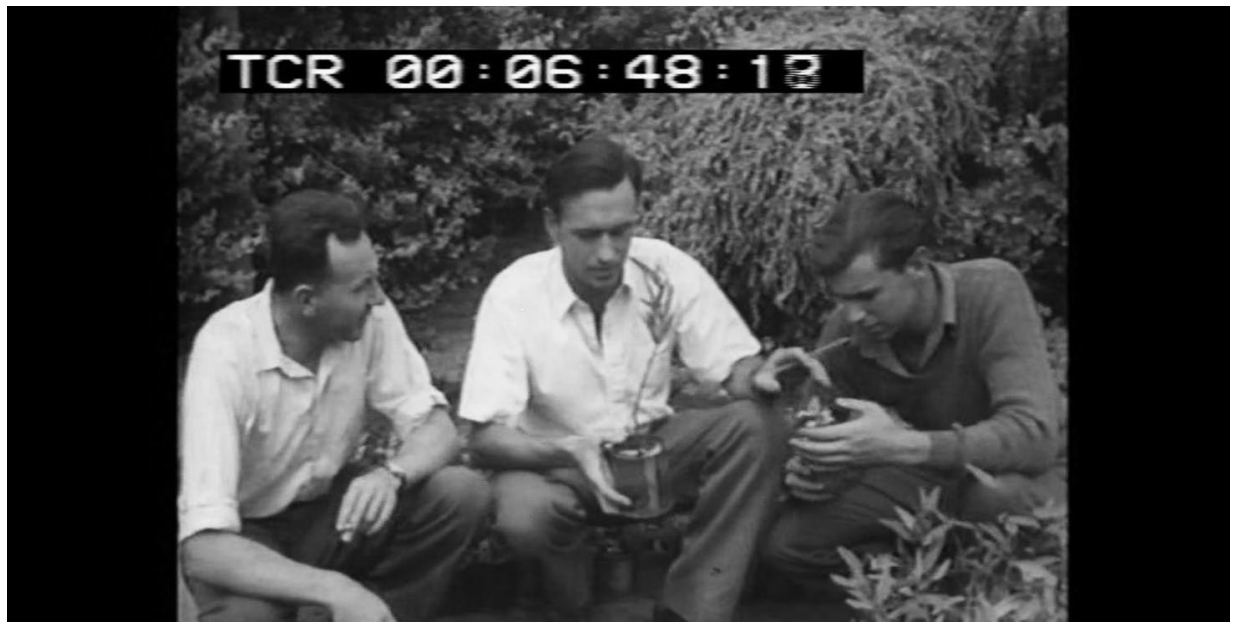

Figure 7: The expert portrayed as patriot. The botanist Noel Beadle (centre) and colleagues with 'land saving seedlings' at Condobolin Government Station in western New South Wales.

Source: Cinesound Productions, Australia is Developing a Dust Bowl (1943), National Film and Sound Archive.

At his headquarters we see Beadle and his team. They are growing saltbush and other shrubs 'to replant the devastated land', with results 'already being achieved with the land-saving seedlings' (Figure 7). ${ }^{94}$ From Condobolin, Beadle started out in the late 1930s with just a Chevrolet sedan for transport. From here he produced a landmark study, published by the Soil Conservation Service in 1948 as The Vegetation and Pastures of Western New South Wales, with Special

93 Noel C. W. Beadle, The Vegetation and Pastures of Western New South Wales, with Special Reference to Soil Erosion (Sydney: Department of Conservation of New South Wales, 1948). On fine native pasture, see his 'Soil Erosion in Western New South Wales', Journal of the Soil Conservation Service of New South Wales 1 (April 1945): 1. Beadle resigned from the Soil Conservation Service in 1946, became senior lecturer in botany at the University of Sydney, and in 1954 was made Foundation Professor of Botany at the University of New England. He authored a number of publications on vegetation of the Sydney region and the continent and received recognition for his achievements from the University of Sydney, the University of New England, the Royal Society of New South Wales (1982), the Ecological Society of Australia (1985), and the Soil Conservation Service of New South Wales (1988). See Whalley Head, 'Beadle, Noel Charles William (1914-1998)', Council of Heads of Australasian Herbaria, Australian National Herbarium (2007), www.anbg.gov.au/biography/beadlenoel.html; Breckwoldt, The Dirt Doctors, 117-18.

94 Cinesound Productions, Australia is Developing a Dust Bowl; Beadle, 'Soil Erosion in Western New South Wales'. 
Reference to Soil Erosion. ${ }^{95}$ The map is still used by many who 'marvel at its accuracy' given the conditions under which he produced it. In July 1944, the Sydney Morning Herald described Beadle's report as a 'monumental' survey of '150,000 square miles of semi-arid and arid grazing country' in the west. He had mapped 25 different vegetation areas and their corresponding soil types and noted the vulnerability of those soils to erosion, while he recorded the changes caused to them by overstocking. ${ }^{96}$ Beadle was passionate about protecting new pasture growth in the west from the destructive impacts of sheep overstocking. ${ }^{97}$ Along with a range of US and Australian experts in the 1940s, he acknowledged a wide range of interrelated factors contributing to wind erosion. Among them were drought and wartime pressures, including the lack of transport to move stock out. But his research confirmed that 'the cause of all erosion in western New South Wales can be traced ultimately to either over-grazing or timber removal or to a combination of these two factors' ${ }^{98}$ His findings were reiterated in the print and film media who put graziers (sheep farmers) on notice.

To emphasise and interpret this message, in Australia is Developing a Dust Bowl, Hall introduces an actor playing the role of a conservation farmer. He introduces himself: 'I speak as a farmer.' He warns that 'land devastation and erosion is largely due to ignorance and exploitation', to 'over-destruction of natural timbers and herbage', and to 'overstocking of the land'. Our 'farmer' acknowledges economic and other pressures that contribute to overstocking. But his emphasis on culpability builds as he is framed in dramatic close-up to highlight the idea that 'If we continue to flog the productive earth to death for a little more profit, posterity will pay a bitter price' ${ }^{99}$ Then the tone of the farmer's voice shifts. He adds angrily, 'that is fatal. If we do not turn from

95 NSW Soil Conservation Zones and Condobolin Station are shown in 'Soil Conservation Zones', Journal of the Soil Conservation Service of New South Wales 1 (July 1945): 36; Beadle, The Vegetation and Pastures of Western New South Wales.

96 Head, 'Beadle, Noel Charles William (1914-1998)'; 'On the Land: Soil Erosion in West', Sydney Morning Herald, 31 July 1944.

97 Breckwoldt, The Dirt Doctors, 118; on Beadle's experimentation with contour furrows in western New South Wales, see 117.

98 See also Hugh Hammond Bennett, who quoted J. Macdonald Holmes, The Erosion-pastoral Problem of the Western Division of New South Wales (Sydney: University of Sydney, 1938) in Soil Conservation (New York: McGraw-Hill, 1939), 935. On Holmes, see G. P. Walsh, 'Holmes, James Macdonald (1896-1966)', Australian Dictionary of Biography, adb.anu.edu.au/biography/holmes-james-macdonald-10527. For earlier reporting, and on South Australia, see Francis Ratcliffe, Flying Fox and Drifting Sand: The Adventures of a Biologist in Australia (Sydney: Pacific Books, 1970); Jock Pick, Australia's Dying Heart (Melbourne: Melbourne University Press, 1942).

99 On close-ups and mid-shots in newsreels of the period discussed in the American context, see Dunaway, Natural Visions, 45. 
exploitation to conservation we shall without question destroy our national heritage' (Figure 8). The 'farmer' heaps blame on his fellow farmers in a terrible warning, while the narrator, Peter Bathurst, turns to biblical themes, reminding us that 'the land of milk and honey can become a desert and drought is not entirely to blame'.

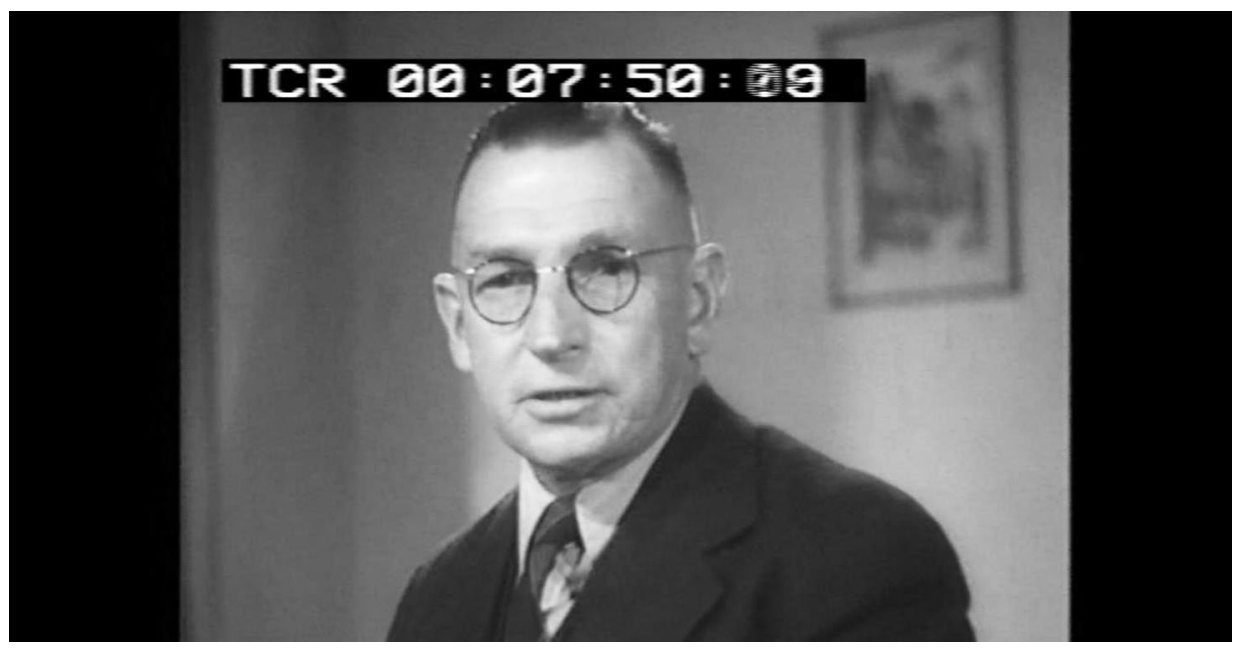

Figure 8: The camera brings the farmer 'up-close and personal' in a tight shot to emphasise the effects of overstocking: 'That is fatal'.

Source: Cinesound Productions, Australia is Developing a Dust Bowl (1943), National Film and Sound Archive.

Illustrated newspaper features and films of the time dedicated much space to capturing shocking images of sheep either being hand-fed scarce feed supplies, dying from starvation and thirst, or dead. The reasons for this were that sheep numbered over 100 million, the idea that 'the nation rides on the sheep's back' was a powerful national myth, and the Riverina was famous for breeding the Merino. All this meant that if images of fat, healthy sheep graced the screens of theatres, Australians could be sure that neither their environment nor their economy were endangered. But as audiences witnessed, in one after another alarming sequence of Hall's film, the sheep of the Riverina were in a shocking condition (Figures 9-11). 


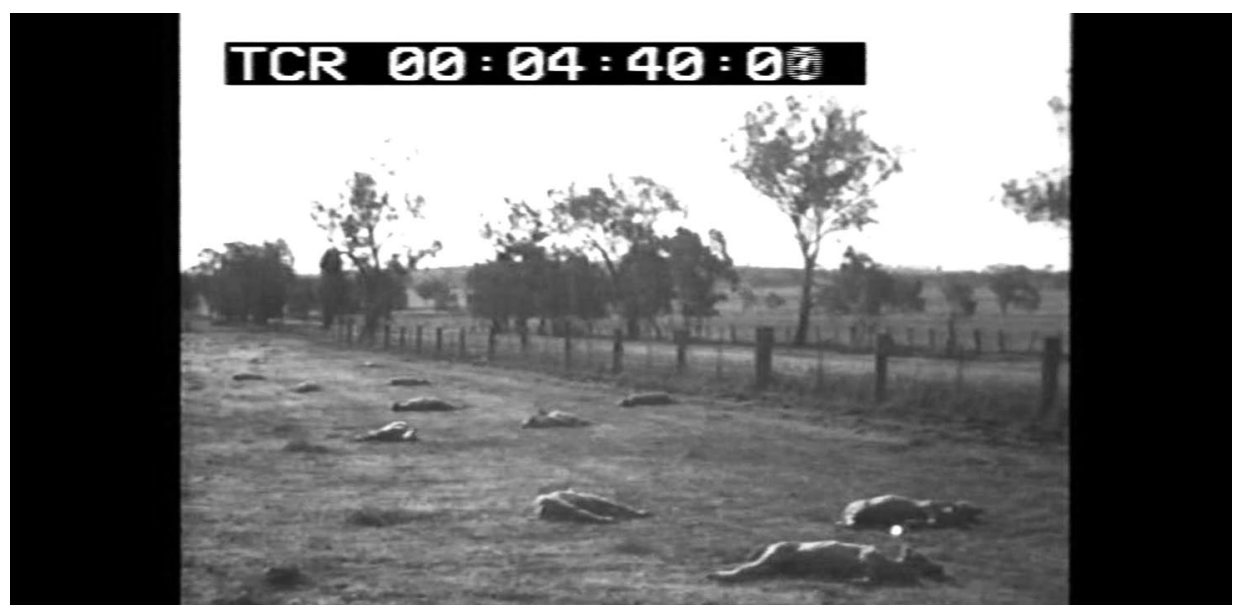

Figure 9: 'The nation riding on the sheep's back'? Turning national myth on its head. Some of these sheep lay dead. But many have been filmed as they lay dying, and all of them lay close to potential feed on the other side of a fenceline. All this indicates an overstocked paddock is to blame.

Source: Cinesound Productions, Australia is Developing a Dust Bowl (1943), National Film and Sound Archive.

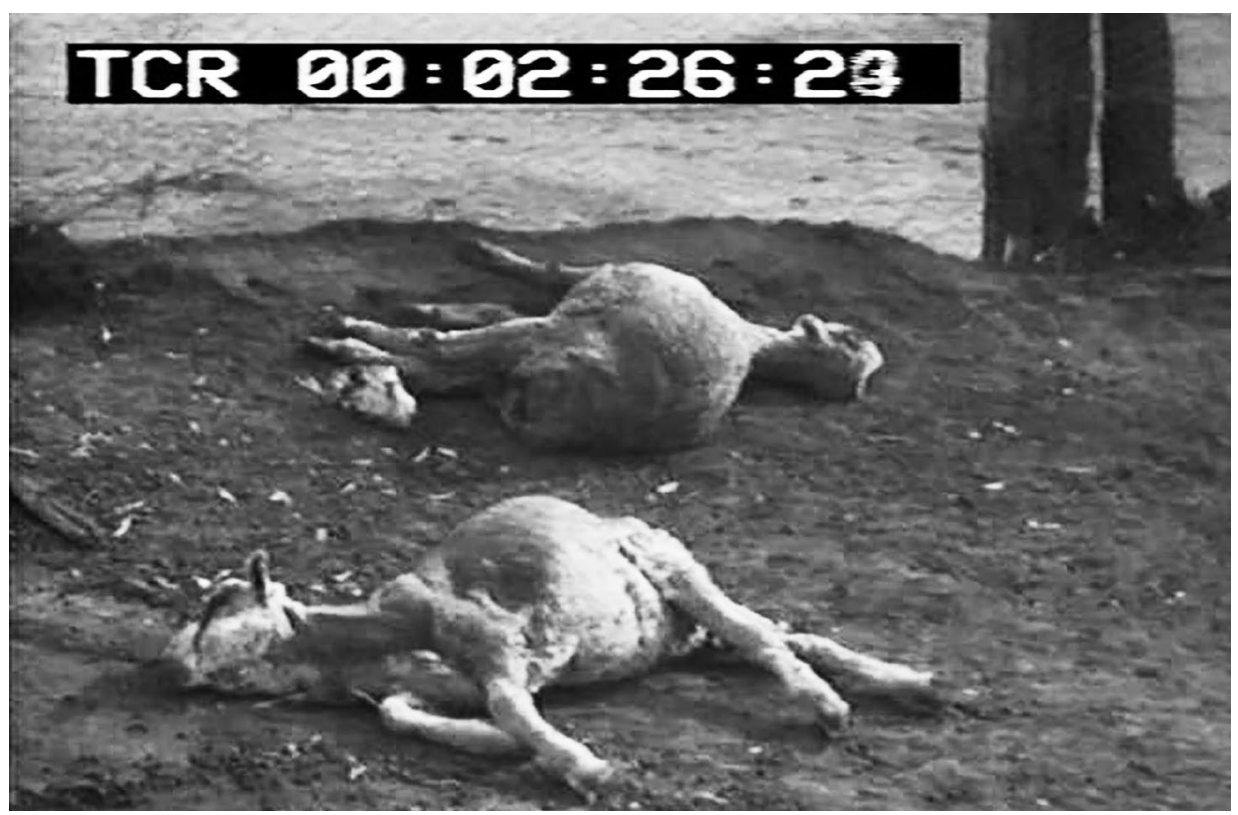

Figure 10: These sheep are alive. In this film sequence they can be seen dying, with no water, feed, or help in sight. Again they are close to potential feed on the other side of a fenceline. This and other such imagery circulating at the time suggests an unpatriotic grazier is at least partly to blame.

Source: Cinesound Productions, Australia is Developing a Dust Bowl (1943), National Film and Sound Archive. 
As Hall's 'dust bowl' sequences unfold, we see a series of images showing tree roots exposed by wind erosion, sand drift and fencelines buried, farms 'blowing away', and huge sand dunes engulfing homesteads. ${ }^{100}$ Symbolic of Australian civilization and national progress, a bullock, sheep, even a horse, and rabbits that were often blamed for erosion, lay dead surrounded by scenes of desolation, still confronting today. Repeated here and throughout other Cinesound erosion films are also stock images of 'crumbling ruins'. They suggest that the process of the decline of Australian civilization to desert is underway. All of this is classic 'dust bowl' imagery - the sound, visuals, and text. ${ }^{101}$ At Condobolin, we have seen Noel Beadle and his team, sleeves rolled up, working to cultivate native shrubs such as saltbush in the battle against a 'dust bowl'.

But how else, Cinesound asks, could this 'potential dust bowl' be stopped? The next combination of images comes as a bit of a surprise to the viewer. This is not a story ending in decline. There is technological salvation. A terrible future can be avoided by 'water conservation plus land conservation. Undeniably,' we are told, 'that is the major post-war job for Australians.' We see litres of fresh water gushing over a dam spillway (Figure 2). In Australia is Developing a Dust Bowl, along with this brief yet dramatic dam scene, there is no text, no narration, no character that mentions methods of water conservation, federal planning authorities, engineering schemes, New South Wales' plans for the Snowy River, the MVWUA, or political campaigns of any kind. We see the dam (Figure 2). Then, as quickly as it flicks across the screen, the film jumps back to images of 'desert' and 'ruined civilizations'.

100 On farmlands 'literally blowing away', see Cinesound Productions, Drought Grips Riverina.

101 It cannot be known whether or not, like his contemporaries, popular writer Ion L. Idriess and filmmaker John Heyer, Ken Hall was directly influenced by the Pare Lorentz US Resettlement Administration film The Plow that Broke the Plains. It is most likely that as a documentary filmmaker of standing who had spent time working in the US, Hall was very familiar with Lorentz' work. However, what is certain and of most interest here, is that Hall was familiar with the US national Dust Bowl narrative and the key sets of imagery utilised to express it. On the films of Lorentz, see Dunaway, Natural Visions and 'New Deal Jeremiads', Environmental History 12, no. 2 (April 2007): 308-12; for a transnational analysis of the films of John Heyer and Pare Lorentz in the Australian/US context, see Bailey, Dust Bowl: Depression America to World War Two Australia and "'Dust bowls", TVAs and Snowy River waters'; Williams, 'Heyer, John'; 'International Documentary Filmmaker', 248-53. 


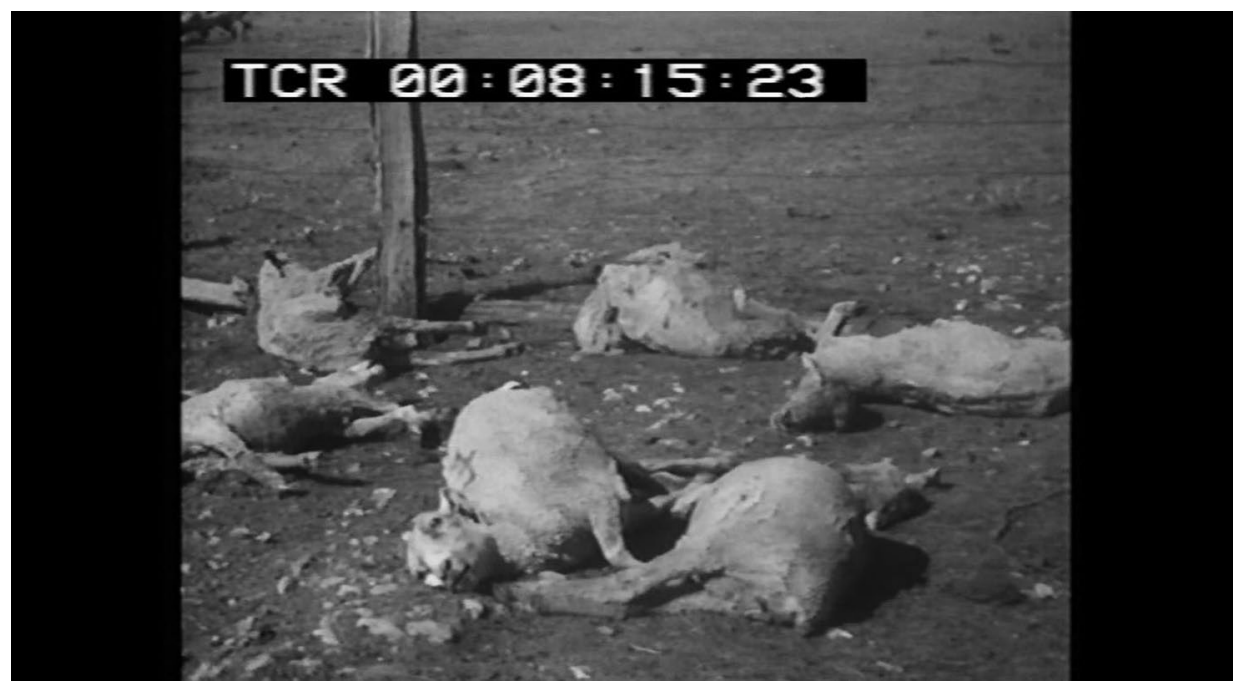

Figure 11: 'Victims of ruthless exploitation'. At a 1944 MVWUA meeting, members argued that diverting the Snowy's waters 'as far westward as is humanly possible' would save sheep from 'extinction' and prevent soil erosion. ${ }^{102}$ Hall shows sheep that are both dead and dying, yet are often close to pasture on the other side of a fenceline in final scenes that shock. A further comment on both patriotism and the nation riding on the sheep's back.

Source: Cinesound Productions, Australia is Developing a Dust Bowl (1943), National Film and Sound Archive.

What does this sudden switch from dam to 'desert' mean? Was Cinesound predicting that without the New South Wales dam-building vision, the nation would see its food bowl turn to 'dust bowl'? Yes, narrator Peter Bathurst warns, 'in north-west New South Wales, the sands of the desert creep eastward, creep up to good properties, creep over them, forced inexorably on by the wind that comes from the west' (Figure 12).

$102 \mathrm{Mr}$ Heason of Hay district feared 'extinction' due to 'want of conserved fodder'. Mr Washington (Leeton Shire) argued for diversion westward in 'Notes of a Deputation which Waited on the Acting Prime Minister on the 22nd May, 1945', Representing the Murrumbidgee Valley Water Users' Association, Commonwealth of Australia Department of Post-war Reconstruction, Snowy River Hydro Electric Scheme-Representations by or on Behalf of Municipalities and Organisations: File No. /44/485, National Archives of Australia, series A9816, item 1946/307 Part 9. 


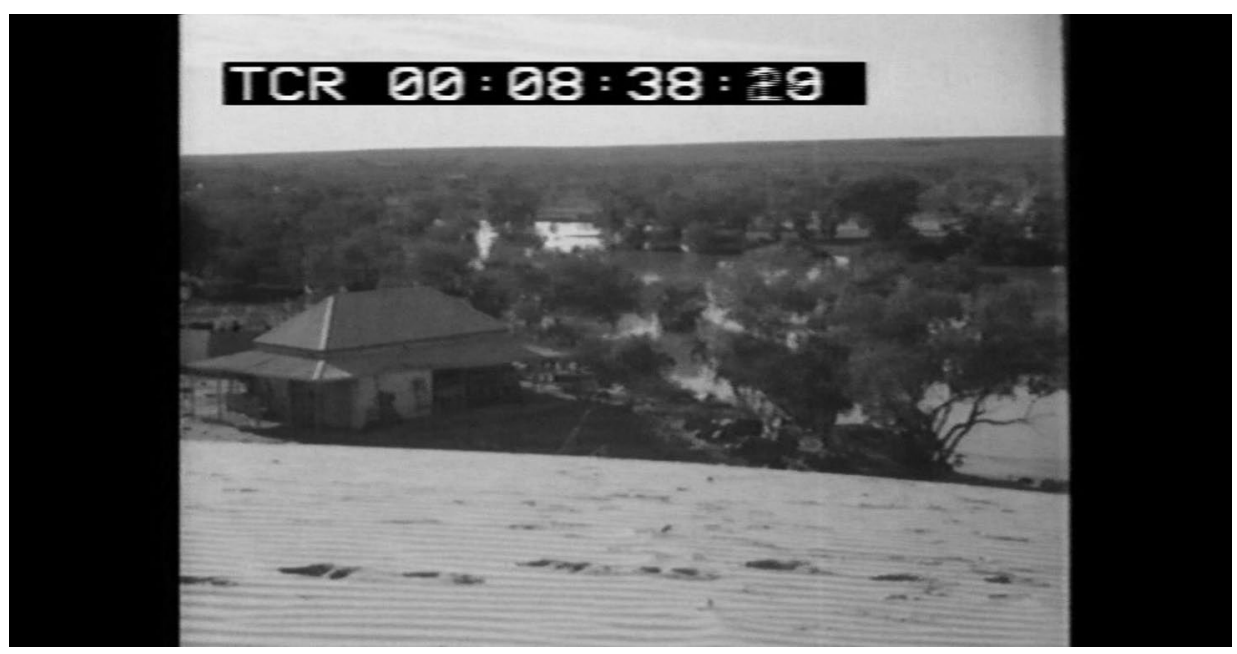

Figure 12: Classic 'dust bowl' imagery as captured by US filmmakers and US photographers, including Arthur Rothstein in his Farm Security Administration photographs of Cimmaron County, Oklahoma, and Amarillo, Texas. ${ }^{103}$ Here, sand drift appears to 'creep up to' New South Wales properties and 'creep over them'. Source: Cinesound Productions, Australia is Developing a Dust Bowl (1943), National Film and Sound Archive.

If the New South Wales water conservation proposal does not go ahead, more of civilization will disappear just like this — he adds: 'this ... was a homestead. This ... was a township' (we see crumbling ruins). Here, the fertile soil has 'gone in a red pall blowing towards the sea and the men and women who had wrestled with this country have moved on'. The message is that dust bowl migration has begun in the north-west and now this 'dust bowl' is spreading into the Riverina, the New South Wales food bowl. 'Back in the Riverina,' we are warned, 'a dust storm is gathering.' Here, the surface soil is 'gone. Not temporarily, but for good.' The symbol of the dam is now pertinent to all that follows. The music whips into a frenzy as a storm sweeps away topsoil (Figures 12 and 13). An image of a little lamb replaces images of hundreds of sheep, dead, dying, or caught in the swirling dust as a storm stirs. The little lamb struggles to its feet. It symbolises Australian prosperity but it also has a double meaning. The new-born lamb symbolises 'America's effort', which, if emulated by the Australian nation, would see Australia and its great symbol of economic progress - the sheep - again rise to its feet (Figure 14). Cinesound tells us that although America has 'not yet conquered the evil', it has made 'great forward strides' in the battle against erosion. By 'rising up unitedly', Bathurst explains, 'America' has 'fought its Dust Bowl problem'.

103 For example, see Arthur Rothstein, Abandoned farm in the dust bowl area. Oklahoma, April 1936, Library of Congress Prints and Photographs Division, hdl.loc.gov/loc.pnp/pp.print. 


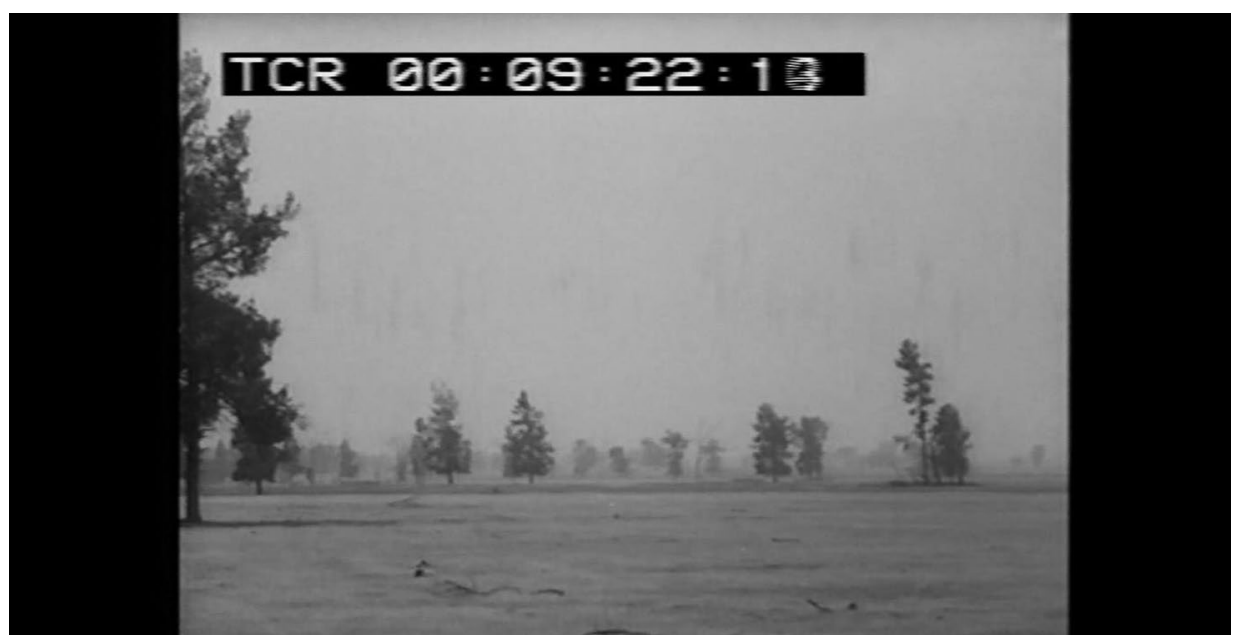

Figure 13: Airborne dust is captured on film rising in the Riverina, a warning that there may be more to come.

Source: Cinesound Productions, Australia is Developing a Dust Bowl (1943), National Film and Sound Archive.

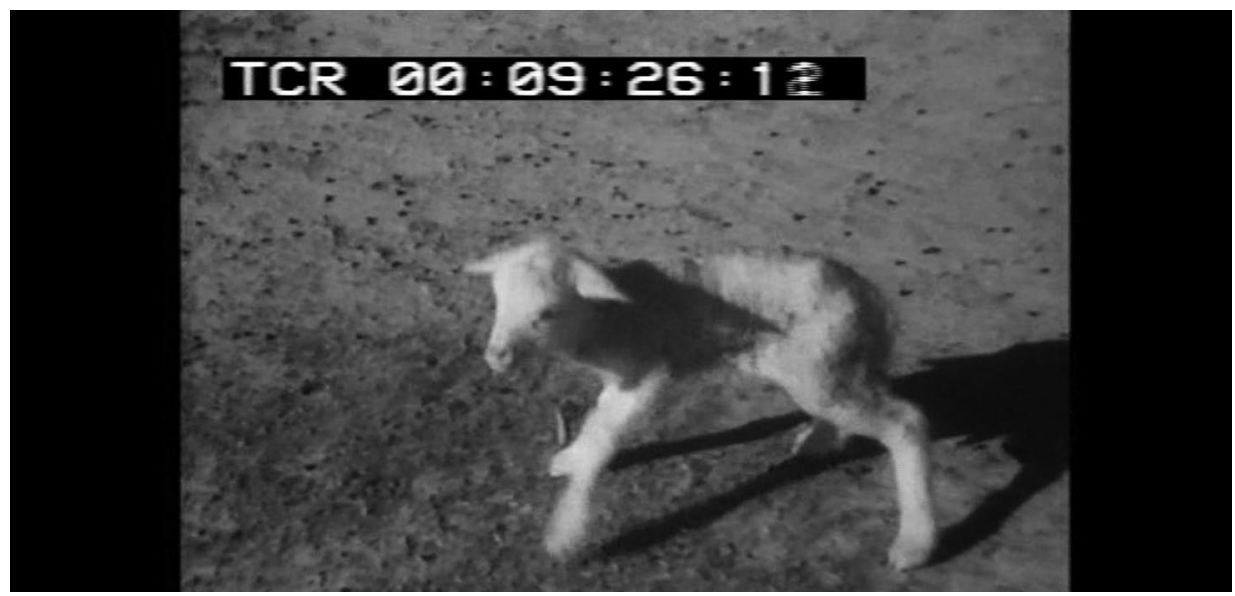

Figure 14: In Australia is Developing a Dust Bowl a little lamb symbolises 'America's effort' to fight its 'Dust Bowl problem'. Australia too, can again rise to its feet like this.

Source: Cinesound Productions, Australia is Developing a Dust Bowl (1943), National Film and Sound Archive.

Soil conservation is promoted, as noted, in this film. The image of the dam, however, indicates more - that the American 'great forward strides' against the Dust Bowl involved the building of enormous dams. ${ }^{104}$ However, it was a distortion to suggest, as this and other imagery then in circulation did,

104 Cinesound Productions, Australia is Developing a Dust Bowl. 
that these dams 'beat America's Dust Bowl problem' on the southern Great Plains. ${ }^{105}$ The US Bureau of Reclamation did build dams in the arid west, such as Boulder Dam on the Colorado River (more commonly known today as Hoover Dam) and Friant Dam in San Joaquin Valley, California. Nonetheless, Hall argues, 'we Australians must do the same because we have exactly the same problem'. ${ }^{106}$

Nor was the New South Wales problem of overstocking 'exactly the same' as the primary issue of over-ploughing for wheat on the southern Great Plains as reiterated in US Dust Bowl narratives. Huge dams were unlikely to solve either problem - but the meaning to Australians and Americans of that much-invoked concept of a 'dust bowl' was that they were very much 'the same problem'. This is clear in Hall's overarching message that permanent civilization is doomed to fail in Australia if the New South Wales plan to divert Snowy waters westward for irrigation does not go ahead. We see the sheep and the grazier who are blamed for the developing 'dust bowl', as national mythology is turned on its head: 'millions and millions of sheep on the move powder the dry soil into dust', while 'the rest is easy for a high wind' (Figures 15 and 16). ${ }^{107}$

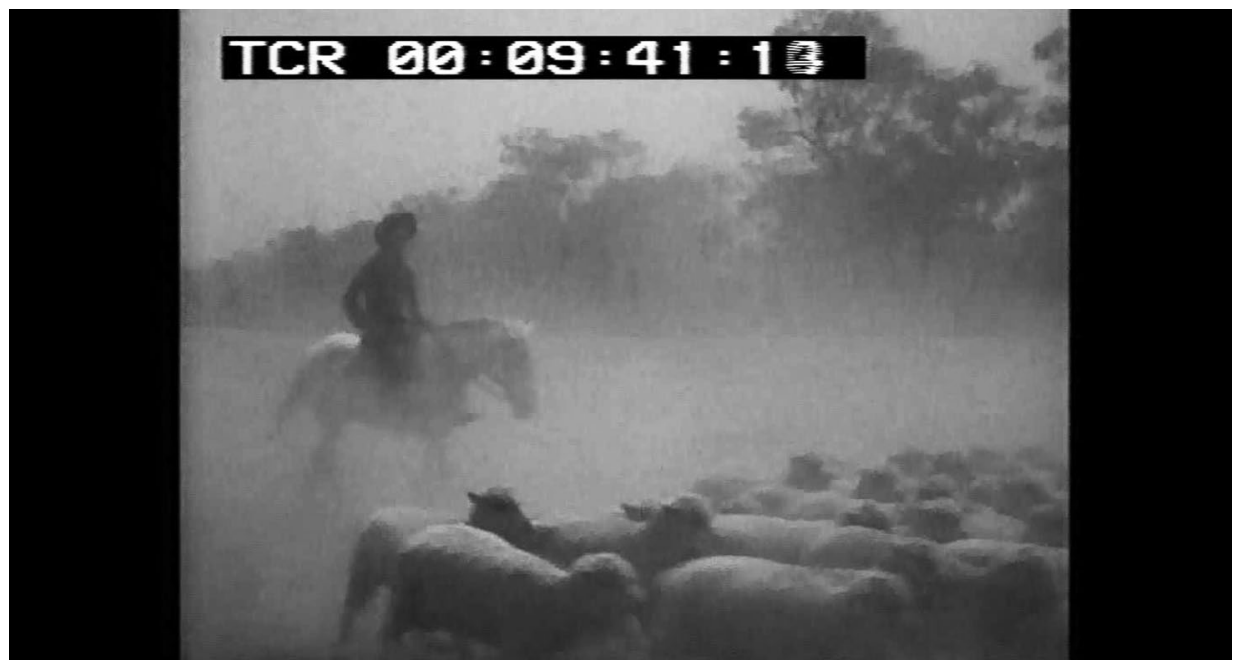

Figure 15: Again, the national symbolism of the grazier and his sheep is reinterpreted as 'millions and millions of sheep on the move' are seen to 'powder the dry soil into dust', raising it to obscure their own presence in this 'developing dust bowl' image. Source: Cinesound Productions, Australia is Developing a Dust Bowl (1943), National Film and Sound Archive.

105 On water strategies for the Dust Bowl, see Donald E. Green, Land of the Underground Rain, 134-5; Cooke, The Future of the Great Plains, 76-7.

106 Boulder Dam is located at the Nevada-Arizona border. Boulder Dam was actually officially named Hoover Dam after the nation's 31st President, Herbert Hoover. Unofficially, after he left office, the name Boulder Dam was commonly used and it was only officially restored in 1947.

107 The 'millions of sheep' scene was originally created by Ken Hall for an earlier film called The Squatter's Daughter. Verhoeven, Sheep and the Australian Cinema, 65. 
Then Australia is Developing a Dust Bowl closes with a caution accentuated by the lowering pitch of a threatening musical score:

We and our descendants want to live here permanently and found the good earth for permanence. For the earth in the long run supports our cities and our secondary industries too. It is not too much to say that if we do not face up to and meet this problem determinedly, then the future of our nation is at stake. ${ }^{108}$

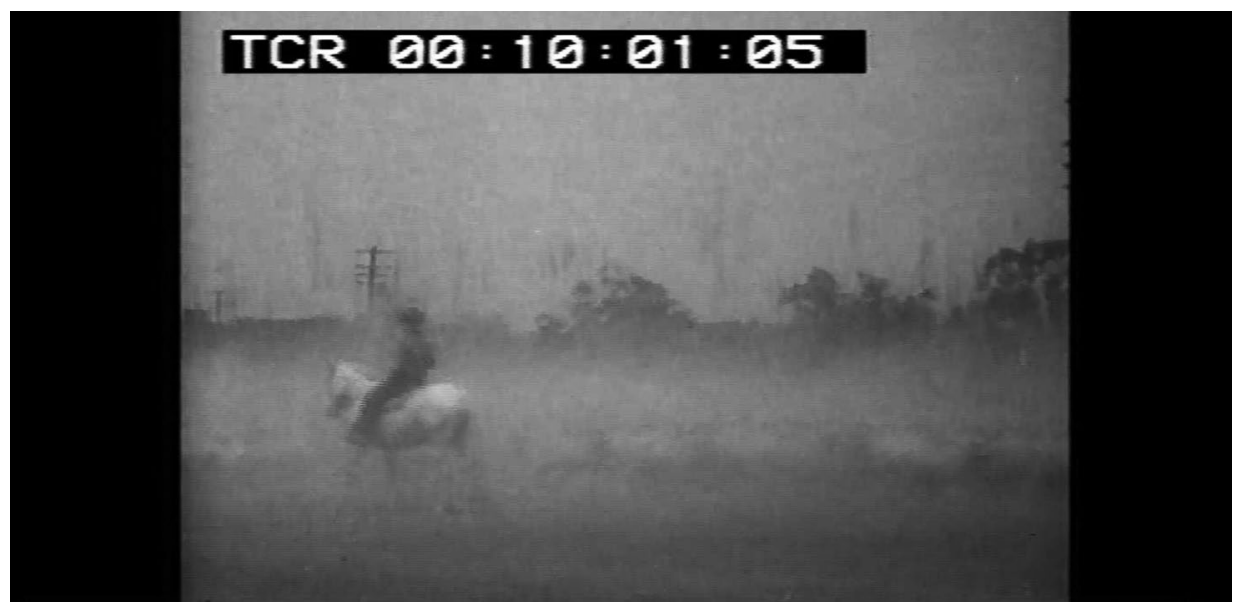

Figure 16: With this imagery, Hall suggests that 'The future of our nation is at stake', due to graziers and sheep, obscured by the dust they are raising in this imagery.

Source: Cinesound Productions, Australia is Developing a Dust Bowl (1943), National Film and Sound Archive.

\section{Screening the film: 'Grave danger' of a 'dust-bowl similar to that of the U.S.A.'109}

In Australia is Developing a Dust Bowl, the appearance of Hall's model dam is brief. Yet contrasted against 'dust bowl' imagery, when screened to parliamentarians, it generated expressions of a real faith in engineering as the answer to aridity, soil erosion, and drought. After viewing Australia is Developing a Dust Bowl and Drought Grips Riverina, Premier McKell called for public screenings in all

108 Cinesound Productions, Australia is Developing a Dust Bowl.

109 Mr Fadden, in Prime Minister's Department, 'Extract from House of Representatives Debate, 16 November, 1944: Inland Australia' sighted (signed) by J. J. Dedman, Minister for War Organisation of Industry and C.S.I.R. Dewar Wilson Goode Collection, series 5: Arid Zone, Box 33, item GOOD00215, 'Watering Inland Australia 1944', July-December, State Library of Victoria. 
picture shows'. He believed this would inspire all members of the public to support his government's soil, forest, and water conservation efforts, including, no doubt, diversion of the Snowy River westward to develop the MIA. ${ }^{110}$

Crayton Burns reported for the Argus on urgent discussions that immediately followed the second Canberra screening. When panicked parliamentarians described dust storms, the emergency needs of graziers, and the need for a Snowy scheme, they reflected Hall's combination of imagery-one dam, set against so much suffering and decay, and all of this framed by an acute awareness of the US Dust Bowl. ${ }^{111}$ Newspapers described the 'erosion menace', quoting the federal member for Darling, J. J. Clark: 'my electorate is being blown into sea'. In the days following the screening, parliamentary members Charles Adermann (for Maranoa), Albert Smith (for Wakefield), and Leslie Haylen (for Parkes) responded to the footage by calling for urgent financial relief for farmers. ${ }^{112}$ They hailed the efforts of 'newspapers and film companies' in publicising drought and erosion 'so forcibly'. Haylen hoped Australia would 'not continue to convert good farming land into dust bowls'. Along with Prime Minister's Press Secretary Don Rodgers and Capitol Theatre manager M. J. Moir, Haylen called these 'splendid' films and called for them to be screened to the public, to stimulate their thinking. ${ }^{113}$ Federal Country Party leader Arthur Fadden reacted with a warning to the House of Representatives of a 'grave danger' at home of a 'dust-bowl similar to that of the U.S.A.' ${ }^{114}$ Visiting Canadian High Commissioner Thomas C. Davis had just returned to Canberra from a visit to the Riverina and the press reported his 'alarm and distress at signs he had seen of the dust bowl in Australia'. As a solution, he encouraged the Snowy diversion plan, stressing that with water 'many difficulties of drought and soil erosion by wind can be overcome'. Minister for Commerce and Agriculture William Scully argued that ‘25 million would be needed for water conservation and irrigation schemes for the eastern areas of Australia' and he called on the government to support

110 See ‘No Fodder Reserves Available[;] Relief Likely in Summer'.

111 In 'Conference Urged on Erosion', Burns described scenes from Australia is Developing a Dust Bowl, where 'even rabbits' were seen to be 'dying from hunger and thirst'.

112 Adermann was the Country Party representative for the seat of Maranoa, Queensland; Smith (Labour) held the South Australian seat of Wakefield; poet, nationalist, and politician Haylen (Labour) held the seat of Parkes in south-west Sydney.

113 Adermann referred to the footage on 17 November 1944: Commonwealth of Australia Parliamentary Debates, 17th Parliament, 2nd session (26th September - 1 December 1944) 180: 1894. See Gaha's comments on 1949, Smith's on 1973-4, and Haylen's on 2117. For the comments on Rodgers' international documentary films, and Moir's comments on 'non-fictional films' see 'Readers' Views', Canberra Times, 24 November 1944. 114 Mr Fadden, in Prime Minister's Department, 'Extract from House of Representatives Debate, 16 November, 1944: Inland Australia', sighted (signed) by J. J. Dedman, Minister for War Organisation of Industry and C.S.I.R. Dewar Wilson Goode Collection, series 5: Arid Zone, Box 33, item GOOD00215, 'Watering Inland Australia 1944, July-December', State Library of Victoria. 
the 'huge post-war water conservation scheme being planned by New South Wales'. Without such a water conservation scheme for inland areas, he argued, 'any form of post-war rural development was worthless' ${ }^{115}$

Parliamentarians had seen the dust blowing outside and on screen. They had seen and heard the sounds and sights of crop failure, heat, animal suffering and death in the Riverina they lived in and represented. On screen, they saw a 'dust bowl' moving from Broken Hill towards the Riverina and they heard of a catastrophic threat to the nation. And in contrast, just for a moment, they saw Hall's one image of a dam suggesting a simple way to dominate and control aridity, drought and erosion in inland areas, kill 'dust bowls', save millions of sheep, develop their region under the auspices of a Commonwealth project, and spur national progress in a modern, postwar world-something, the film suggested, America had done. When the war was over, Australia could do this too.

Hall's films had an impact but they did not help to provide a quick solution. Across the decade, advocates for a Murrumbidgee diversion scheme, driven by the efforts of the MVWUA, were to become increasingly frustrated. The state of Victoria's claims on Snowy River water, and their corresponding rival narratives, continued to threaten the New South Wales dream of doubling the Murrumbidgee Valley's capacity for irrigation. ${ }^{116}$ Finally, in 1949 the Commonwealth took control of the Snowy project. ${ }^{117}$ An independent body, the Snowy Mountains Hydroelectric Authority, was finally established by agreement with Victoria and New South Wales, while McKell, now Australian Governor-General, pressed the button that set off the first blast. But, in the end, no one state was to control

\footnotetext{
115 'Mr. Clark Says the Darling Electorate Being Blown into Sea: Erosion Menace', Barrier Miner, 15 November 1944. The press of the day often gave films various titles. This writer identified this film as 'Ken Hall's documentary film "Soil Erosion and the current Drought"'.

116 For details of the Victorian rival vision and the film, print, and broadcast media imagery constructed to support their campaign, see Bailey, "'Dust bowls", TVAs and Snowy River waters'and Dust Bowl: Depression America to World War Two Australia.

117 On the Commonwealth taking control under Australia's defence powers, see Wigmore, Struggle for the Snowy, 141-2. On Snowy waters' increasing carrying capacity, see 'Snowy River Diversion Advocated'.
} 
all that water. ${ }^{118}$ The waters of the Snowy River were diverted to both the MIA and the Murray River Valley. Both irrigation and hydropower were developed through a construction process that was completed in 1974, on a project that has been hailed as 'an international historical engineering landmark' by the American Society of Civil Engineers. ${ }^{119}$

\section{Conclusion}

Hall placed the deafening sound of water rushing over an enormous dam wall, the sight of water splashing, pouring, flooding - only momentarily-against 'dust bowl' imagery where wind could be heard howling and sand drifted as far as the eye could see. His dam sequence was momentary. Yet this contrasting imagery in wartime soil and water conservation films, such as Australia is Developing a Dust Bowl, triggered emotionally charged debate about water diversion at the national and state levels. There is a great deal of meaning embedded in Hall's one brief image of a dam. It reflected a wider circulation of the same contrasting imagery in print and on radio that grew out of a period of wartime national grief, unthinkable levels of personal loss, and great cultural and technological change-along with the ascension of Labour governments. With barely a word about water, Hall's model dam suggested 'dust bowl' salvation for Australia. When he contrasted the dam against long sequences portraying devastation in the Riverina, Hall provided a real justification for the kind of postwar happy ending Australians already imagined, the kind they wanted. It was one filled with water, a population of many millions, thriving sheep, hydropower, employment for all, and most importantly, those longed-for irrigated green garden landscapes that, fed by enormous dams, would once and for all eliminate deserts — at least in New South Wales anyway.

\footnotetext{
118 On McKell and the first blast, see National Archives of Australia, '60 years of the Snowy Mountains Hydro-Electric Scheme' (2015), naa.gov.au/collection/snapshots/power/index.aspx; The Snowy Hydro authority more recently became a corporation with the states as shareholders; eventually 99 per cent of Snowy River water was diverted west. On this history of debate surrounding the projected and realised environmental impacts, see Claire Miller, Snowy River Story: The Grassroots Campaign to Save a National Icon (Sydney: ABC Books, 2005); George Sedden, Searching for the Snowy: An Environmental History (St Leonards, NSW: Allen \& Unwin, 1994); Wigmore, Struggle for the Snowy; Grahame Griffin, 'Selling the Snowy: The Snowy Mountains Scheme and National Mythmaking', Journal of Australian Studies 79 (2003). On the Snowy construction (1951-75), see Brad Collis, Snowy: The Making of Modern Australia (Canberra: Tabletop Press, 1990). In the early stages of construction, Kaiser Walsh Perini Raymond (KWPR), an American consortium, built Tumut Pond Dam, the Tumut 1 Pressure Tunnel and Surge Tank, the Eucumbene-Tumut Tunnel, and the largest dam, Eucumbene. On KWPR and a tunnelling medal awarded to Max Stermole, see Museum Victoria, 'Snowy Mountains Scheme, Australia, 1956', item NU 42218 Medal-Snowy Mountains Scheme, Australia, 1956 (November 2012), collections.museumvictoria.com.au/items/415673.

119 Grahame Griffin, 'Selling the Snowy', 1.
} 
With his model of Woronora Dam in Australia is Developing a Dust Bowl, Hall tried to connect to this sentiment by posing a question. His image offered Australians a choice between an arid, drought-stricken, soil-eroded past and a new beginning after the war. As Richard White has described it in the American case, this suggested water conservation in terms of a maximum use of resources through an improved, controllable, machine-like nature. ${ }^{120}$ It suggested salvation from US-style 'dust bowls'. And not just any salvation, but deliverance inspired by the engineering achievements of the US Bureau of Reclamation in the American west and the TVA. It drew attention to Burrinjuck Dam as a magnificent example of similar dual-purpose projects at home. It suggested that the example of Burrinjuck and the expansion of the Murrumbidgee River's capacity was crucial to the development of the state. Most importantly, that one dam sequence symbolised the connection between all of this and the state of New South Wales as the saviour of the nation. Central to it all was the image of one little lamb struggling to its feet. It indicated that the US and Australia had the same environmental problems of aridity, drought and erosion and could apply the same solutions - engineering. This entire set of ideassheep myth, irrigation hopes, enthusiasm for US dam-building achievements, wartime sentiment, 'dust bowl' fears, political ambition, national vision, and a transnational perspective - existed not just in 1943. These historical ideas and perspectives can still be seen and heard today. All that is needed is to sit back and watch and listen to this footage of a model dam that had been built by Ken Hall in a 'rented space on the lot of the closed down Pagewood Studios' in Sydney. ${ }^{121}$

120 On the contemporary idea of a machine-like nature, see White, The Organic Machine.

121 Hall, Directed by Ken G. Hall, 155. See 155-6 for details of model construction. For a description of the narrative linking dams to nationhood in Dad Rudd M.P., see Cathcart, The Water Dreamers, 235. 
This text is taken from International Review of Environmental History, Volume 2, 2016, edited by James Beattie, published 2016 by ANU Press, The Australian National University, Canberra, Australia. 